\title{
Enhanced Histaminergic Neurotransmission and Sleep-Wake Alterations, a Study in Histamine H3-Receptor Knock-Out Mice
}

\author{
Elise Gondard', Christelle Anaclet', Hidéo Akaoka', Rui-Xian Guo',3, Mei Zhang ${ }^{1,4}$, Colette Buda', \\ Patricia Franco', Hidehito Kotani ${ }^{2,5}$ and Jian-Sheng Lin*,' \\ I'Integrative Physiology of the Brain Arousal Systems, Lyon Neuroscience Research Center, INSERM UI028-CNRS UMR 5292, Faculty of \\ Medicine, Claude Bernard University, Lyon, France; ${ }^{2}$ Banyu Pharmaceutical Co., Tsukuba, Japan
}

\begin{abstract}
Long-term abolition of a brain arousal system impairs wakefulness $(\mathrm{W})$, but little is known about the consequences of long-term enhancement. The brain histaminergic arousal system is under the negative control of $\mathrm{H} 3$-autoreceptors whose deletion results in permanent enhancement of histamine (HA) turnover. In order to determine the consequences of enhancement of the histaminergic system, we compared the cortical EEG and sleep-wake states of H3-receptor knockout $(\mathrm{H} 3 \mathrm{R}-/$ - ) and wild-type mouse littermates. We found that $\mathrm{H} 3 \mathrm{R}-1$ - mice had rich phenotypes. On the one hand, they showed clear signs of enhanced HA neurotransmission and vigilance, i.e., a higher EEG $\theta$ power during spontaneous $W$ and a greater extent of $W$ or sleep restriction during behavioral tasks, including environmental change, locomotion, and motivation tests. On the other hand, during the baseline dark period, they displayed deficient $W$ and signs of sleep deterioration, such as pronounced sleep fragmentation and reduced cortical slow activity during slow wave sleep (SWS), most likely due to a desensitization of postsynaptic histaminergic receptors as a result of constant HA release. Ciproxifan ( $\mathrm{H} 3$-receptor inverse agonist) enhanced $\mathrm{W}$ in wild-type mice, but not in $\mathrm{H} 3 \mathrm{R}-$ / - mice, indicating a functional deletion of $\mathrm{H} 3$-receptors, whereas triprolidine (postsynaptic HI-receptor antagonist) or $\alpha$-fluoromethylhistidine (HA-synthesis inhibitor) caused a greater SWS increase in H3R - / - than in wild-type mice, consistent with enhanced HA neurotransmission. These sleep-wake characteristics and the obesity phenotypes previously reported in this animal model suggest that chronic enhancement of histaminergic neurotransmission eventually compromises the arousal system, leading to sleep-wake, behavioral, and metabolic disorders similar to those caused by voluntary sleep restriction in humans.

Neuropsychopharmacology (2013) 38, I015-1031; doi:I0.1038/npp.2012.266; published online I3 February 2013
\end{abstract}

Keywords: wakefulness; histamine; H3-receptor; sleep; motivation; behavior

\section{INTRODUCTION}

During wakefulness (W), the cerebral cortex is maintained in an activated state by a large subcortical ascending network made up of several arousal systems. It is well known that long-term abolition of an arousal system impairs wakefulness (reviewed in Moruzzi, 1972; Lin, 2000; Jones, 2005), but, curiously, little is known about the sleep-wake consequences of long-term enhancement, which can lead to insomnia or, conversely, a wake deficit

*Correspondence: Dr J-S Lin, Integrative Physiology of the Brain Arousal Systems, Lyon Neuroscience Research Center, INSERM UI028-CNRS UMR 5292, Faculty of Medicine, Claude Bernard University, 8 av. Rockefeller, 69373, Lyon, Cedex 08 69373, France, Tel: (33) 478777 I I6, Fax: (33) 478777 150, E-mail: lin@univ-lyon I.fr ${ }^{3}$ Present address: Department of Physiology, Zhongshan Medical College, Sun Yat-Sen University, Guangzhou 510080, P.R. China

${ }^{4}$ Present address: Department of Pharmacology, Guangzhou Medical College, Guangzhou 510182, China

${ }^{5}$ Present Institution: MSD K.K., a subsidiary of Merck \& Co., Inc. Whitehouse Station, NJ, USA

Received 17 August 2012; revised 28 October 2012; accepted 30 November 2012; accepted article preview online 2 January 2013 after exhausting the arousal systems. It can also be associated with voluntary sleep restriction in humans. Such sleep-wake disorders result in a deterioration of brain and body functions (Spiegel et al, 1999; 2004; Revel et al, 2009). To gain insights into wake regulation under pathophysiological conditions, it is essential to study animal models with chronic enhancement of the arousal systems.

The widespread projecting histamine (HA) neurons constitute a major wake-promoting system (reviewed in Lin, 2000; Lin et al, 2011b). Located in the tuberomammillary nucleus and adjacent areas of the posterior hypothalamus (Panula et al, 1984; Watanabe et al, 1984; Lin et al, 1986; 1993), they exhibit the most wake-selective discharge pattern so far identified in the brain (Sakai et al, 1990; Vanni-Mercier et al, 2003; Takahashi et al, 2006). HA modulates the neuronal activity of target structures through $\mathrm{H} 1-, \mathrm{H} 2-, \mathrm{H} 3-$, and perhaps H4-receptors. Activation of postsynaptic H1-receptors elicits cell depolarization and tonic neuronal discharge, leading to general brain arousal, while activation of postsynaptic H2-receptors increases neuronal excitability and discharge rate and therefore could promote cortical arousal (McCormick, 
1992; Brown et al, 2001; Haas et al, 2008). Finally, $\mathrm{H} 3$-receptors on both HA and non-HA neurons play a role as auto- and hetero-receptors (Arrang et al, 1983; Schwartz et al, 1991) and are involved in sleep-wake control through negative feedback on HA neurons (Lin et al, 1990; 2011a; Vanni-Mercier et al, 2003). Drugs impairing HA neurotransmission increase slow wave sleep (SWS), whereas those causing acute enhancement of transmission, such as H3receptor inverse agonists, promote waking (Lin et al, 1988; Monti, 1993; Lin et al, 1996; 2008; Passani et al, 2004; Parmentier et al, 2007).

Knockout (KO) mice lacking HA synthesis, and thus HA neurotransmission, are characterized by an impaired cortical EEG, somnolence, and a wake deficit when high vigilance is required, e.g., lights-off or environmental change (Parmentier et al, 2002). Thus, the use of a permanently HA-deficient model has demonstrated the major role of this arousal system in maintaining the brain awake when faced with behavioral challenges.

The present study was designed to determine the consequences of permanent enhancement of HA neurotransmission using H3-receptor KO mice. In this genotype, deletion of the H3-receptor gene abolishes negative feedback on HA neurons, causing constantly high HA turnover and neurotransmission (Takahashi et al, 2002; Toyota et al, 2002). We compared the cortical EEG and sleep-wake parameters of the KO mice with those of wild-type littermates under baseline conditions and after behavioral or pharmacological tests and revealed rich and apparently 'contradictory' phenotypes providing new insights into wake regulation under conditions of chronic activation of the brain arousal systems.

\section{MATERIALS AND METHODS}

\section{Animals and Genotype Identification}

All experiments followed the European Ethics Community Directive (86/609/EEC), and every effort was made to minimize the number of animals used and any pain and discomfort. The general protocol of chronic sleep-wake recording in mice was approved by the Service of Animal Protection, Préfecture du Rhône, France ( $\mathrm{N}^{\circ}$ 69388200).

Histamine (HA) H3-receptor knockout (H3R KO or H3R - /-) mice were descendants of the mouse strain generated by Takahashi et al. (2002) and kept on the C57BL/ $6 \mathrm{~J}$ genomic background. They were transferred to our laboratory animal facility after seven backcrosses. To ensure genetic congeniality of experimental animals used for the present study, male H3R $-I-$ mice were backcrossed with female wild-type $(\mathrm{H} 3 \mathrm{R}+I+$ or $\mathrm{WT})$ mice, and the generated $\mathrm{H} 3 \mathrm{R}+I-$ mice were crossed between themselves resulting in both heterozygotes and homozygotes. Only littermate homozygote $\mathrm{H} 3 \mathrm{R}+I+$ and H3R $-I-$ mice ( $n=15$ pairs) were used in this study to ensure that any detected phenotype resulted from the deletion of H3-receptor gene rather than the genetic heterogeneity between individual animals.

At the age of 4 weeks, tail biopsies were performed and mice were genotyped using PCR with a kinase phosphoglycerate primer: WT Sens: $5^{\prime}$-TGT CCC CGA GCC CTG TGA GCC TGC-3'; WT Antisens: $5^{\prime}$-GGT CGA AGC GCC AAG CCC CAT TGC-3'; KO sens: $5^{\prime}$-GGA GTC CTG AGG CGC AAG TTC CCT AG-3'; KO Antisens: 5'-CCA AAG AAC GGA GCC GGT TGG CGC C-3'. The expected products were 280 bps and 361 bps for KO and WT respectively. These two sets of primers were included concomitantly and PCR was performed using 1 cycle of $15 \mathrm{~min}$ at $95^{\circ} \mathrm{C}$ followed by 35 cycles of $30 \mathrm{~s}$ at $95^{\circ} \mathrm{C}, 30 \mathrm{~s}$ at $62^{\circ} \mathrm{C}$, and $1 \mathrm{~min}$ at $72^{\circ} \mathrm{C}$, finished by one cycle at $72{ }^{\circ} \mathrm{C}$ for $10 \mathrm{~min}$. The whole reaction mix was then fractionated on a $2 \%$ agarose gel, and the PCR product was visualized by ethidium bromide staining (Figure 1).

\section{Surgery}

Only male mice were used in this study. At the age of 12 weeks and with a body weight of 23-28 g, the animals were chronically implanted with four cortical electrodes (goldplated tinned copper wire, $\emptyset=0.4 \mathrm{~mm}$; Filotex, Draveil, France) and three muscle electrodes (fluorocarbon-coated gold-plated stainless steel wire, $\emptyset=0.03 \mathrm{~mm}$; Cooner Wire, Chatworth, CA), under deep isoflurane anesthesia (2\%, $200 \mathrm{ml} / \mathrm{min}$ in oxygen mixed with gas anesthesia machine, TEM, France), to record electroencephalograms (EEG) and electromyograms (EMG) and to monitor their sleep-wake cycles. All electrodes were previously soldered to a multichannel electrical connector and each was separately insulated with a covering of heat-shrinkable polyolefin/polyester tubing. The cortical electrodes were inserted into the dura through two pairs of holes $(\varnothing=0.5 \mathrm{~mm})$ made in the skull, located, respectively, in the frontal $(1 \mathrm{~mm}$ lateral and anterior to the bregma) and parietal ( $1 \mathrm{~mm}$ lateral to the midline at the midpoint between the bregma and lambda) cortices. The EMG electrodes were inserted into the neck muscles. Finally, the electrode assembly was anchored and fixed to the skull with Super-Bond (Sun Medical Co., Shiga, Japan) and dental cement. This implantation allowed stable polygraphic recordings to be made for more than 5 months.

\section{Polygraphic Recording and Data Acquisition and Analysis}

After surgery, the animals were housed individually in transparent barrels $(\varnothing 20 \mathrm{~cm}$, height $30 \mathrm{~cm})$ in an insulated sound-proof recording room maintained at an ambient temperature of $22 \pm 1{ }^{\circ} \mathrm{C}$ and on a $12 \mathrm{~h}$ light/dark cycle (lights on at 7 a.m.), food and water was available ad libitum. After a recovery period of one week, the mice were

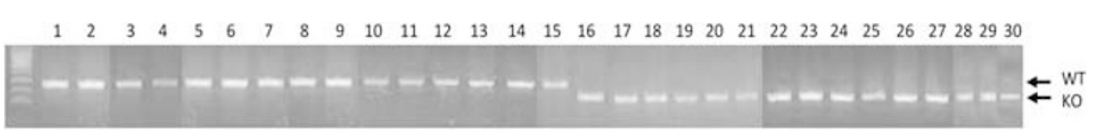

Figure I PCR genotyping of mouse tail DNA showing the presence of H3-receptor gene (36I bps) in the wild type (WT) mice (animals I-I5) and its absence (replaced by a 280 bps allele) in their knockout (KO) littermates (animals 16-30). 
habituated to the recording cable for one more week before starting polygraphic recordings.

Cortical EEG (ipsilateral frontoparietal leads) and EMG signals were amplified, digitized with a resolution of 256 and $128 \mathrm{~Hz}$, respectively, and computed on a CED 1401 Plus (Cambridge Electronic Design, UK). Using Spike2 (Cambridge Electronic Design) script and with the assistance of spectral analysis using the fast Fourier transform, polygraphic records were visually scored by 30 -sec epochs for wakefulness (W), slow wave sleep (SWS), and paradoxical sleep (PS) according to previously described criteria validated for mice (Valatx, 1971; Valatx and Bugat, 1974; Parmentier et al, 2002; Anaclet et al, 2009). In order to evaluate the contrast of sleep-wake states between light and dark phases and as a criterion of sleep-wake circadian rhythms, we used the light/dark ratio for sleep stages (dark/ light for $\mathrm{W}$ ), obtained by $8 \mathrm{~h}$ sleep-wake amounts before lights-off, divided by those after lights-off.

Cortical EEG power spectrum analysis was performed on recordings during the dark phase period between 7 and 10 p.m. and during the light phase between 11 and 2 p.m. in baseline conditions. To avoid any variation caused by the positioning of the cortical electrodes, the cortical EEG used for power spectral density analysis was captured from frontoparietal leads and set with reference to the bregma, lambda, and midline in all mice. EEG power spectra were computed for consecutive 4-sec epochs within the frequency range of $0.5-60 \mathrm{~Hz}$ using a fast Fourier transform routine. The data were collapsed in $0.5 \mathrm{~Hz}$ bins. On the basis of visual and spectral analysis, epochs containing artefacts occurring during active waking (with large movements) were visually identified and omitted from the spectral analysis when the threshold value in the $0-1 \mathrm{~Hz}$ band was exceeded. The power densities obtained for each state were summed over the frequency band of $0.5-60 \mathrm{~Hz}$ (total power). To standardize the data, all power spectral densities at the different frequency ranges, i.e., $0.5-3.5 \mathrm{~Hz}(\delta) ; 3.5-$ $5.5 \mathrm{~Hz}$ (low $\theta$ ); $5.5-9$ (fast $\theta$ ); $9-20 \mathrm{~Hz}$ (spindle or $\alpha$ ); and $20-60 \mathrm{~Hz}(\beta$ and $\gamma)$, were expressed as a percentage relative to the total power (eg, power in the $\delta$ range/power in the $0.5-60 \mathrm{~Hz}$ range) of the same epochs. To evaluate contrast in the cortical EEG between SWS and W or PS, we used an EEG power ratio determined by the averaged cortical EEG total power density during SWS divided by that during either W or PS.

\section{Experimental Procedures}

In each experiment, recordings were simultaneously made from an equal number (usually in batches of three) of H3R $-I-$ and H3R $+I+$ mice. The mice were submitted to the following experimental procedures.

\section{Spontaneous Cortical EEG and Sleep-Wake Cycle}

After recovery from surgery and habituation to the recording cables, each mouse (15 pairs) was subjected to a recording session of two continuous days, beginning at 7 a.m. During these periods, the animals were left undisturbed to obtain baseline parameters on the cortical EEG, sleep-wake cycle and circadian rhythm. The data from the two sets of mice were then compared.

\section{Sleep-Wake Cycle After Behavioral Tests}

Three tests were used to characterize the behavioral phenotypes of WT and H3R - I - littermates. Sleep-wake recordings were maintained during and $12 \mathrm{~h}$ after the tests, which were performed in a random sequence:

1) A new environment, with mice transferred for $4 \mathrm{~h}$ from their habitual transparent barrel to an opaque rectangular box $(21 \times 30 \mathrm{~cm}$, height $20 \mathrm{~cm}$, with open field). In this test, the ability of the two genotypes to remain awake after this environmental change was tested. Each mouse was subjected to this test four times separated by an interval of 1420 days, twice at 2 p.m. when the animals would normally be sleeping for $\sim 80 \%$ of the time (defined as 'sleep period'; $n=22$ from 11 pairs of mice), and twice at $6 \mathrm{p} . \mathrm{m}$. when they would normally be awake a majority of the time ('awake period'; $n=18$ from nine pairs of mice).

2) A locomotion (wheel) test, which is a motor challenge to study the ability of mice to enhance $\mathrm{W}$ and cortical activation through locomotion. This test consisted of placing mice, for $4 \mathrm{~h}$, on a wheel $(\varnothing=13 \mathrm{~cm}, 5.5 \mathrm{~cm}$ wide) which was composed of two circles, connected by regularspaced bars (length, $5.5 \mathrm{~cm}$; distance between bars, $9 \mathrm{~mm}$ ). The circles and bars were made up of stainless steel wires $(\emptyset=1.5 \mathrm{~mm})$. The hub of the wheel was screwed to a transparent Plexiglas box $(10 \mathrm{~cm}$ long, $7 \mathrm{~cm}$ wide, $28 \mathrm{~cm}$ high) which served to support the wheel and to prevent mice from getting off the wheel. The turning resistance of the wheel was set in such a way that the mice were able, after a few seconds of habituation, to either stay immobilized and fall asleep or to run over the regularly spaced bars to turn it and as a result to remain awake. This locomotion test was essentially voluntary even though the mice had to stay on the wheel during the test. The wheels were equipped with a magnetic detector, allowing quantification and computerization of the wheel turn number and time spent turning every $30 \mathrm{~s}$ by using a homemade data acquisition system. For the test, mice were placed on the wheel, which together with the plexiglas box was placed in each mouse's home barrel to keep them in their familiar environment. The mice stayed on the wheel for $4 \mathrm{~h}$, with food and water available ad libitum. Each mouse was subjected to this test twice separated by an interval of 5-15 days, at 2 p.m. $(n=24$ from 12 pairs of mice) and at 6 p.m. $(n=26$ from 13 pairs of mice). Sleep-wake stages during their stay in the new environment or on the wheel were compared with the baseline recordings for the same group and between genotypes.

3) A test of motivation using palatable food, which consisted of introducing a piece of hard nougat and caramel and a grain of corn, suspended at a height difficult to reach for mice. The ability of the two genotypes to remain awake and catch the tasty food allowed the evaluation of wakefulness driven by motivation. All WT and KO mice were habituated two times to the test in order to avoid neophobic behavior and to determine their interest in the food. The food was then placed at the bottom of their barrel. Only mice which immediately tried to eat the food and consumed it within $2 \mathrm{~h}$ were included in the final test. This was the case for the great majority of the mice.

Each mouse was subjected to this test twice, separated by an interval of 14-20 days, twice at 2 p.m. and twice at 7 p.m. 
( $n=16$ from 8 pairs of mice). The control of this test consisted of sleep-wake recordings after applying the system without food. Sleep-wake stages during the presence of tasty food were compared with those during control of the same group and between the genotypes.

\section{Cortical EEG and the Sleep-Wake Cycle After Pharmacological Administration}

To compare the effects of drugs acting on the histaminergic system, the two mouse genotypes received intraperitoneal injections of the following agents with an interval of at least 7 days between injections, with subsequent recordings for 12 or $24 \mathrm{~h}$. Drug doses were expressed as compound (salt) weight. They were dissolved in $0.1-0.3 \mathrm{ml}$ of saline, fresh before each administration. Mice were injected either with saline alone or containing 1$)$ cyclopropyl-(4-(3-(1 H-imidazol-4-yl) propyloxy) phenyl) ketone (ciproxifan; $1 \mathrm{mg} / \mathrm{kg}$; Bioprojet, Paris, France; $n=10$ ), a potent HA H3-receptor inverse agonist/antagonist (Ligneau et al, 1998); administrations were performed at $10 \mathrm{a} . \mathrm{m}$. when the mice were normally sleeping most of the time ('sleep period') to detect an awakening effect; 2) triprolidine ( $5 \mathrm{mg} / \mathrm{kg}$; ICN, Ohio, USA; $n=14$ ), a HA H1-receptor antagonist (Yanai et al, 1990; McCormick and Williamson, 1991); injections were given at 8 p.m. when the mice would normally be awake most of the time ('awake period') to detect a sedative effect; and 3) (S)- $\alpha$-fluoromethylhistidine $(\alpha-F M H ; 50 \mathrm{mg} / \mathrm{kg}$; Merck, Sharp \& Dohme; $n=18$ ), a specific inhibitor of histidine decarboxylase, the HA-synthesizing enzyme. Injections were given at 4 p.m., in order to reach a significant and important decrease in brain histamine at lights-off (7 p.m.) and in view of the latency of drug action shown previously by Garbarg et al, (1980) and Maeyama et al. (1982).

\section{Statistical Analysis}

All experimental data was firstly tested for their value distribution using Shapiro-Wilk normality test. When the data was non-normally distributed, such as that of body weight and cortical EEG, nonparametric Mann Whitney tests were used. Two-way ANOVA for repeated measures and unpaired Student's $t$-test were used to evaluate the differences between genotypes when the data was normally distributed. This concerned all comparisons of baseline sleep-wake quantitative data between the WT and KO mice. Regarding the comparison between control data (baseline recordings or saline injection) and those after behavioral challenges or pharmacological tests, we applied split plot two-way ANOVA for repeated measures using genotype $(\mathrm{H} 3 \mathrm{R}+I+v s \mathrm{H} 3 \mathrm{R}-/-)$ and experimental condition (control $v s$ treatment) as factors. These tests were followed, if the $\mathrm{p}$ values were significant, by post hoc Bonferroni test, with individual animals served as their own control. The impact of genotype on the behavioral or pharmacological effects was further evaluated by direct comparisons of the net sleep-wake changes between the two genotypes using unpaired Student's $t$-test. All data are expressed as the mean \pm SEM. All tests used were two-tailed with a significance level of alpha set at 0.05 .

\section{RESULTS}

\section{Genotyping and General Observations}

All wild-type (WT or H3R $+/+$ ) mice displayed a strong PCR signal, corresponding to a 361 base pair band (animals 1-15), whereas all H3-receptor gene disrupted (H3R KO or $\mathrm{H} 3 \mathrm{R}-/-$ ) littermates showed a signal corresponding to a 280 base pair band (animals 16-30), indicating the deletion of the histamine (HA) H3R gene (Figure 1).

Like WT mice, H3R - I- mice appeared to develop normally. No obvious abnormalities were detected in general morphology, fertility, spontaneous movement or other behavior under baseline conditions. The number of littermates appeared normal (6-7 per litter). At post-natal $70 \pm 7$ days and before surgical implantation, body weight was similar $(25.9 \pm 0.5 \mathrm{~g} v s 24.5 \pm 0.3 \mathrm{~g}$ in $\mathrm{H} 3 \mathrm{R}+/+$ mice; $n=15$ for each genotype, $p=0.1198$ nonparametric Mann Whitney test). Nevertheless, a difference in body weight appeared with age, the respective weights at 36 weeks were $31.6 \pm 0.8 \mathrm{~g}$ in $\mathrm{H} 3 \mathrm{R}-I-$ mice $v s 29.4 \pm 0.4 \mathrm{~g}$ in WT mice ( $n=15$ for each genotype, $p=0.0250$ nonparametric Mann Whitney test). This body weight difference between genotypes became more noticeable over 45 weeks.

\section{Baseline Sleep-Wake Cycle and Cortical EEG in H3R - I - Mice}

In baseline conditions, the $\mathrm{H} 3 \mathrm{R}$ KO mice exhibited a circadian sleep-wake rhythm quite characteristic of C57BL/ $6 \mathrm{~J}$ mice, with a larger amount of $\mathrm{W}$ during the dark than during the light period (Figure 2a-c). Their sleep-wake amount appeared quite similar to that of the WT counterpart during the light phase, even though there was a tendency for less PS. Immediately following lights-off, however, the KO mice showed major differences in sleepwake. A detailed analysis revealed several specific phenotypes:

A significant decrease in $W$ after lights-off, during darkness and over $24 \mathrm{~h}$. While there was no significant difference between genotypes in terms of total amount of W, SWS and PS during the light phase (Figures $2 \mathrm{~b}$ and $\mathrm{c}$ ), the hourly analysis revealed a sharp and significant decrease in $\mathrm{W}$ immediately after lights-off $[(\mathrm{F}(\mathrm{df} 1=1 ; \mathrm{df} 2=23)=2.44$, $P=0.0002$, two way ANOVA for repeated measures followed by post hoc Bonferroni tests between genotypes) This effect lasted for more than $4 \mathrm{~h}$ (between 19 and $23 \mathrm{~h}$ : $153 \pm 3$ vs $184 \pm 5 \mathrm{~min}$ in $\mathrm{H} 3 \mathrm{R}+/+, p=0.0083$, unpaired Student's $t$-test, Figure $2 \mathrm{~b}$, boxed areas) and was accompanied by a simultaneous and significant increase in SWS and PS. These effects also led to a significant decrease in W and an increase in SWS during darkness and over $24 \mathrm{~h}$. No significant change was found, however, for PS during the same periods (Figure $2 \mathrm{~b}$ and $\mathrm{c}$ ).

A reduced dark/light ratio for $W$ and light/dark ratio for all sleep stages. The above sleep-wake changes during darkness also resulted in reduced light/dark (or dark/light for W) ratios for all sleep-wake states as compared with those of WT littermates (Figure 2b), indicating disturbed circadian sleep-wake rhythms in the KO mice. 

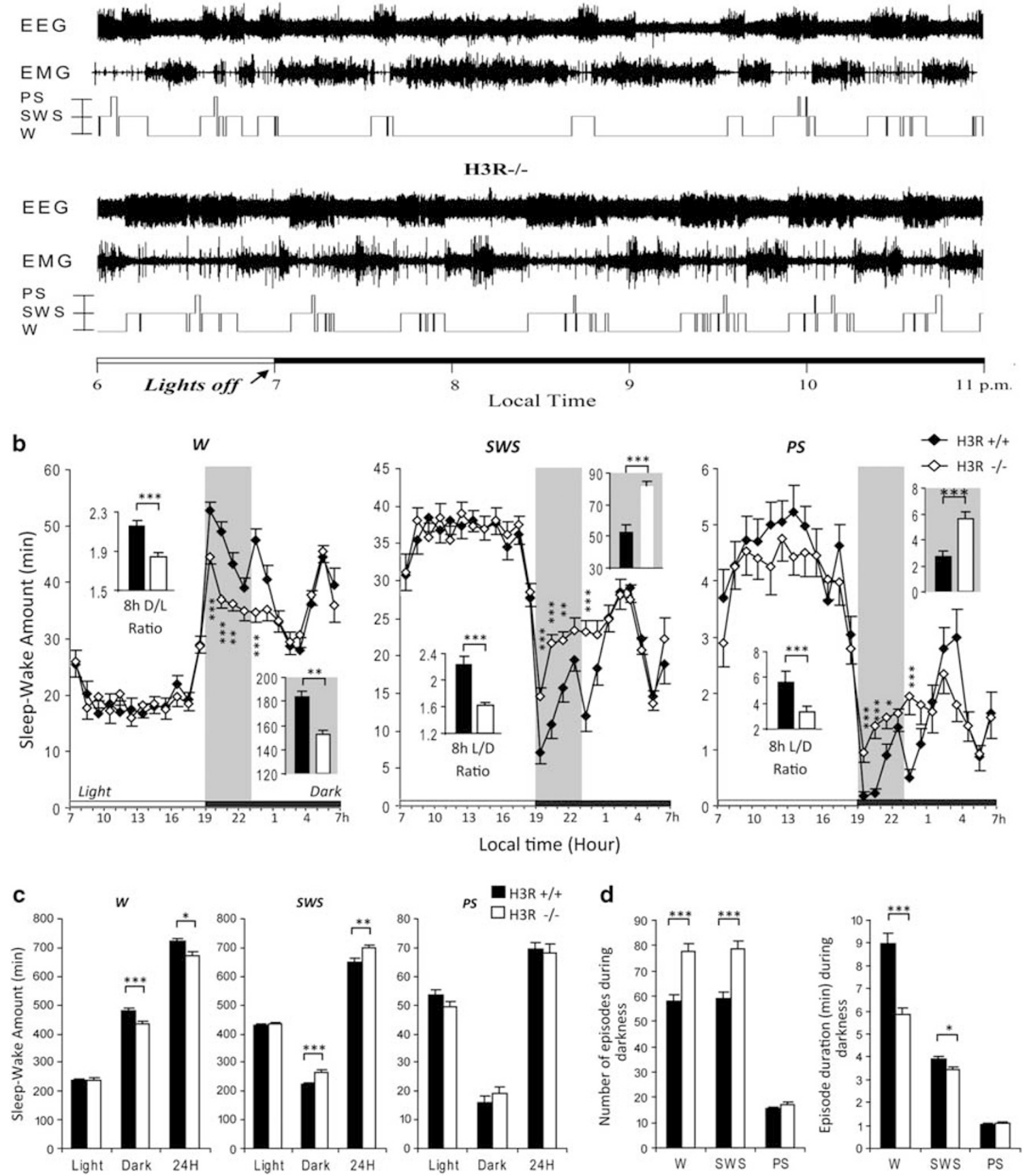

Figure 2 Comparison of spontaneous sleep-wake parameters in H3-receptor $(H 3 R)+/+$ and $-/$ littermates. $H 3 R+/+$, filled symbols and columns; H3R - / - , unfilled symbols and columns. a, Examples of polygraphic recordings and corresponding hypnograms showing the spontaneous sleepwake cycle before and after lights-off. b, mean hourly values ( \pm SEM in min) of the sleep-wake states. The gray areas correspond to the period between 7 and II p.m., and the total values for each sleep-wake state during this period are indicated in the bars with background situated in the right side of each figure. The left side non-background inserted histograms correspond to the light/dark or dark/light (L/D or D/L) ratio of sleep-wake amount before and after lights-off. They were obtained by $8 \mathrm{~h}$ sleep-wake amounts before lights off, divided by those after lights-off or verse versa. c, Means \pm SEM (in min) of the sleep-wake stages for the $12 \mathrm{~h}$ light and dark and $24 \mathrm{~h}$ periods. $\mathrm{d}$, mean values \pm SEM of episode number and duration of each sleep-wake state during the darkness. Note that, compared with H3R + I + mice, H3R - I - mice exhibited I) a deficit of wakefulness (W) immediately after the lights-off (a), during darkness (a, b) and over $24 \mathrm{~h}$ (c) at the expense of slow wave sleep (SWS); 2) a pronounced sleep fragmentation during the darkness (a, d). Other abbreviations: PS, Paradoxical Sleep; EEG, electroencephalogram; EMG, electromyogram. $n=30$, corresponding to $2 \times 24 \mathrm{~h}$ recordings for 15 animals of each genotype. ${ }^{\circ} p>0.05$, ${ }^{*} p<0.05$, ${ }^{*} * p<0.01$, **** $p<0.001$, two way ANOVA for repeated measures (b except for the bar graphics) and unpaired Student's t-test (c, d and bar graphics in b, two-tails).

A pronounced sleep fragmentation during darkness. Like the unchanged total sleep-wake amounts during the light phase, the number of episodes and their duration of each sleep-wake state during this period remained unmodified in $\mathrm{H} 3 \mathrm{R}-/-$ mice. In sharp contrast, they developed a pronounced sleep fragmentation immediately 
a

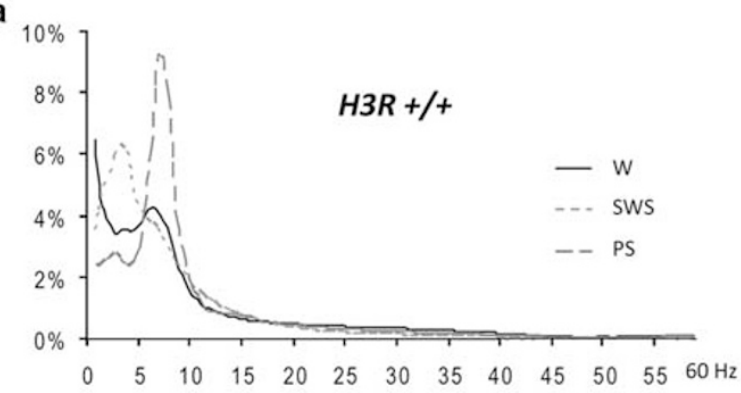

c

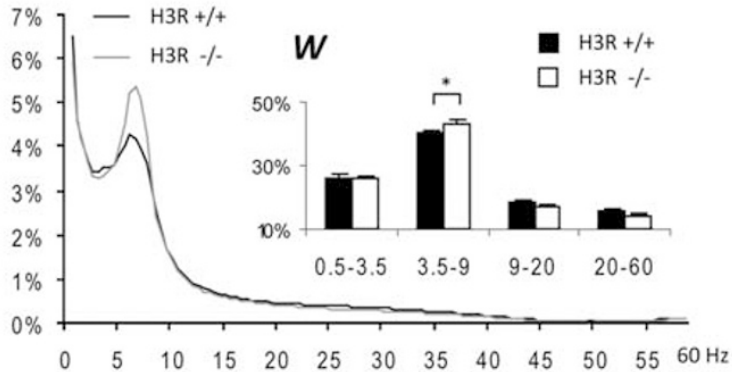

e

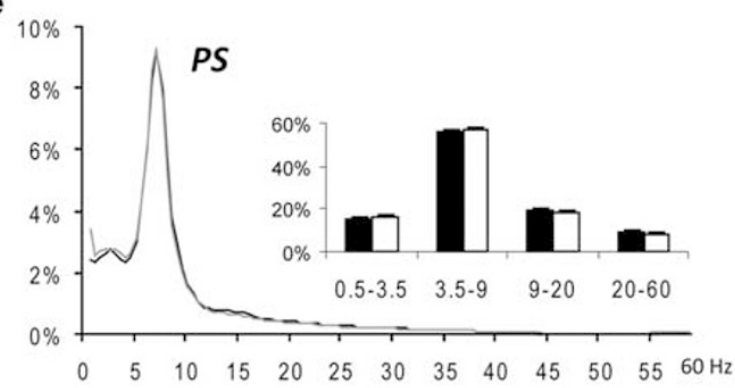

$\mathbf{b}_{10}$

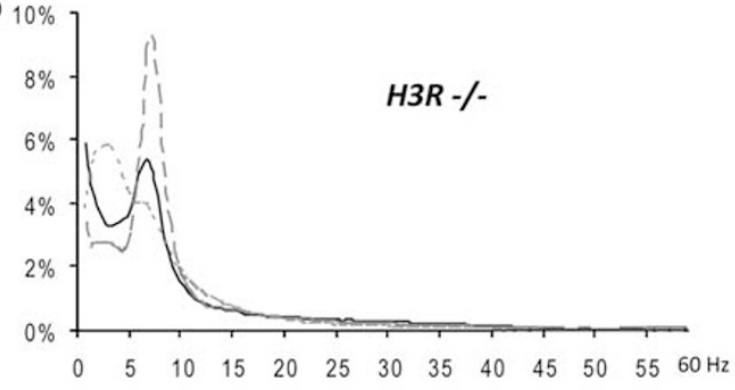

d

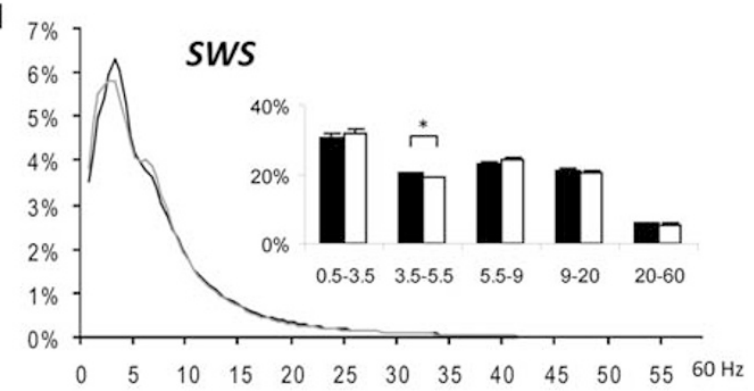

f

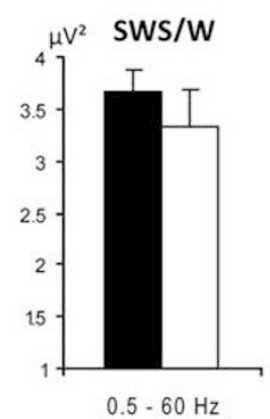

Figure 3 Mean spectral distribution of cortical EEG power density in baseline sleep-wake states in $\mathrm{H} 3 \mathrm{R}+/+$ and $\mathrm{H} 3 \mathrm{R}-/-$ mice. The data were obtained from 16 samples of 8 pairs of littermates by pooling consecutive $4 \mathrm{~s}$ epochs during the period of $7-10$ p.m. (darkness) using the fast Fourier transform routine within the frequency range of $0.5-60 \mathrm{~Hz}$. a-b. Mean percentage power values in each $0.4 \mathrm{~Hz}$ frequency bin. Note the state-dependent profiles of cortical EEG spectra across wakefulness (W), slow wave sleep (SWS), and paradoxical sleep (PS) in H3R + I + (a) and H3R - I - (b) mice. c-e, Mean percentage of cortical EEG power spectrum density (curves) and cortical EEG power band density (bars) in H3R $+/+$ (black line or filled bars) and $\mathrm{H} 3 \mathrm{R}-1$ - (gray line or unfilled bars) mice. Note that the $\mathrm{H} 3-$ - - mice show an increase in theta band $(3.5-9 \mathrm{~Hz})$ during $\mathrm{W}$ and a decrease in slow activity in $3.5-5.5 \mathrm{~Hz}$ range during SWS. f, Cortical EEG SWS/W and SWS/PS power ratio $(0.5-60 \mathrm{~Hz})$ in $\mathrm{H} 3 \mathrm{R}+/+$ (filled bars) and H3R $-/-$ (unfilled bars) mice. ${ }^{*} p<0.05$, nonparametric Mann Whitney test (two tails).

after lights-off, manifested as, for both $\mathrm{W}$ and SWS, a marked increase in the episode number and a decrease in the episode duration during the whole dark phase, e.g., the mean episode number and duration of $\mathrm{W}$ were $78 \pm$ $3 \times 6 \pm 0.3 \mathrm{~min}$ in the $\mathrm{KO}$ mice $v s 58 \pm 3 \times 9 \pm 0.5 \mathrm{~min}$ in WT mice $(P<0.001$, unpaired Student's $t$-test, Figure $2 \mathrm{~d})$. The duration and number of PS episodes remained unchanged during the same period.

An increase in $\theta$ rhythm during $W$ and a decrease in slow activity during SWS after lights-off. From the frontoparietal leads, the cortical EEG of both sets of animals manifested changes across the behavioral states and signs characteristic of C57BL6J mice, i.e., with dominant presence of $\theta$ frequencies, notably during PS and $\mathrm{W}$ (Figure 3a). When the cortical EEG power spectrum analysis was performed at 11 to 2 p.m. (Sleep period), no difference was found between genotypes $(n=8$ pairs of mice). Firstly, the distribution of their mean cortical EEG power spectral density was not significantly modified during either W, SWS or PS. The morphology of their EEG spectra was virtually the same as that of their WT littermates. Secondly, analysis of the mean power density in each cortical frequency band during W, SWS and PS revealed no significant difference between the WT and H3R $-I-$ mice. Finally, their cortical EEG power ratio between SWS and or PS was unchanged: EEG SWS/W: $3.9 \pm 0.3$ in KO vs $3.4 \pm 0.1$ in WT, $p=0.100$; EEG SWS/PS: $2.8 \pm 0.2$ in WT vs $3.1 \pm 0.3$ in KO, $p=0.390, n=8$ pairs of animals in both cases using nonparametric Mann Whitney test.

In contrast, after lights-off (between 7 and 10 p.m.) and simultaneously with the quantitative changes, H3R - Imice showed several cortical EEG phenotypes compared to their WT littermates: i) an increase in the power spectral density in the $\theta$ rhythm during $\mathrm{W}$. This increase, limited to the $3-9 \mathrm{~Hz}$ frequency range, was seen only during $\mathrm{W}$ 
(Figure 3c). ii) a decrease in the power spectral density of slow activity during SWS. This decrease, limited to the frequency range of $3.5-5.5 \mathrm{~Hz}$, was seen only during SWS (Figure 3d). iii) the power spectral density in the $\theta$ rhythm during PS remained identical between the genotypes (Figure 3e). There was no change in the other bands of the cortical EEG during any of the behavioral states. The cortical EEG SWS/W or SWS/PS power ratio tended to decrease in the H3R $-I-$ mice owing to the increased $\theta$ power during $\mathrm{W}$ and its decrease during SWS. These changes were, however, not statistically significant with the number of samples used (Figure $3 \mathrm{f})(n=8$ pairs of mice, nonparametric Mann Whitney test).

All the above phenotypes were identified during darkness. Such a clear association with darkness is also seen with other models affecting HA (Parmentier et al, 2002, Haas et al, 2008). Although the mechanisms involved remain to be determined, HA is most likely linked with circadian rhythm control and brain clock gene expressions (Abe et al, 2004; Hong et al, 2006).

\section{Effects of Behavioral Challenges on Sleep-Wake Parameters}

A new environment. When placed in a new cage, both genotypes appeared to be interested in the new environment, as manifested by a large amount of spontaneous locomotion and exploratory behavior, such as ambulation and rearing. When tested between 2-6 p.m., both of them responded to the new environment with an extended $W$ associated with a significant decrease in SWS and PS, as compared with their own baseline values. However, no significant difference was found between genotypes when their net sleep-wake changes were compared (data nonshown). For W, for example, $+62 \pm 5$ in WT $v s+52 \pm$ $4 \mathrm{~min}$ in $\mathrm{KO}, n=22$ from 11 pairs of mice $[\mathrm{F}(1,40)=2.358$, $p=0.13$ using a two way ANOVA followed by post hoc Bonferroni tests using Genotype and Experimental condition as factors].

Conversely, when placed in a new cage between 6-10 p.m., both WT and $\mathrm{H} 3 \mathrm{R}-I-$ mice responded to the environmental change with significant sleep-wake changes and with greater effects seen in $\mathrm{H} 3 \mathrm{R}-1-$ mice (Figures $4 \mathrm{a}$ and $\mathrm{b}$ ) as attested by two way ANOVA followed by post hoc Bonferroni tests using Genotype and Experimental condition as factors. Indeed, there are significant interactions between the two factors: $\mathrm{F}(1,40)=5.284,4.431$ and 8.137 and $p=0.027,0.042$ and 0.007 , respectively for $\mathrm{W}$, SWS and PS. Bonferroni tests confirmed significant sleepwake changes within the genotype in the new environment (Figure 4b). Comparisons of the net sleep-wake changes between phenotypes using unpaired Student's $t$-tests also confirmed significantly greater effects in the KO than in WT mice. Indeed, their increase in $\mathrm{W}$ was $40 \%$ superior to that of WT mice, or $+73 \pm 5 v s+52 \pm 8 \mathrm{~min}(n=22$ from 11 pairs of mice, $p=0.027$, Figure $4 c$ ). Their decrease in SWS or PS during the $4 \mathrm{~h}$ stay is also significantly greater than that of the WT littermates (Figures $4 \mathrm{~b}$ and c).

A locomotion (wheel) test. The transfer of the mice to the wheel during $4 \mathrm{~h}$ elicited, at any of the tested times, a great amount of running activity in both genotypes even though they had the possibility to find a position to stay immobilized and fall asleep. During the 2-6 p.m. test, this running activity was accompanied by a significant increase in W and decrease in SWS and PS in both genotypes as compared respectively with their own baseline amount. No significant differences between genotypes were found, however, in terms of their net motor and sleep-wake changes. For $\mathrm{W}$, for example, $+88 \pm 10$ in $\mathrm{WT} v s+$ $70 \pm 9 \mathrm{~min}$ in $\mathrm{KO}, n=26$ from 13 pairs of mice, $[\mathrm{F}(1,48)=$ $1.927, p=0.17$ using two way ANOVA followed by post hoc Bonferroni tests using Genotype and Experimental condition as factors].

During the 6-10 p.m. test, the running activity of the mice was also accompanied by significant sleep-wake changes in both genotypes with, however, greater effects seen in $\mathrm{H} 3 \mathrm{R}-1-$ than in WT mice (Figures $5 \mathrm{a}$ and $\mathrm{c}$ ), as demonstrated firstly by two way ANOVA showing significant interactions between the Genotype and Experimental condition, for $\mathrm{W}$, for example, $\mathrm{F}(1,48)=4.541, p=0.038$. Significant increase in $W$ and decrease in SWS were evidenced using post hoc Bonferroni tests within genotype (Figure 5c) and greater sleep-wake changes were further confirmed by direct comparison of the net sleep-wake changes between genotypes showing a greater extension of $\mathrm{W}$ in the $\mathrm{KO}$ mice (ie, $39 \%$ more, or $+68 \pm 6 \mathrm{~min} v \mathrm{~s}$ $+49 \pm 7 \mathrm{~min}$ in WT mice, $n=26$ from 13 pairs of mice, $p=0.038$, unpaired Student's $t$-test), associated with a larger decrease in SWS and PS (Figure 5d). In $\mathrm{H} 3 \mathrm{R}-1-$ mice, interestingly, whatever their wake amount, either inferior (2-6 p.m. test, $144 \pm 8$ in $\mathrm{KO} v s \quad 162 \pm 9 \mathrm{~min}$ in WT) or superior $(6-10$ p.m. test, Figure $5 \mathrm{c})$ to that of the WT littermates, their wheel turning remained at a lower level than that of the WT mice (see example in Figure 5b), in line with an overall decrease in locomotion or activity, identified previously in H3R KO mice (Toyota et al, 2002; Nuutinen et al, 2011). This dissociation between vigilance state and locomotion indicates that the extended $\mathrm{W}$ seen in the $\mathrm{KO}$ mice is not due to an enhanced locomotion.

Test of motivation-driven wakefulness. Placement of palatable food (a piece of nougat and caramel and a grain of corn, suspended at a height almost out of reach) in the mouse barrel, elicited, in either genotype, a behavioral activation, manifested as an increased locomotion and numerous attempts to climb, catch and eat the food. The $\mathrm{H} 3 \mathrm{R}-1-$ mice appeared to be more active than the WT littermates as seen from our EMG recordings.

During the 2-6 p.m. test, i.e., within the sleep period, the presence of palatable food resulted in a significant increase in $\mathrm{W}$ over the whole $4 \mathrm{~h}$ period in the two genotypes, mainly at the expense of SWS (Figure 6a and b). There are significant interactions between Genotype and Experimental condition for all the sleep-wake states. For W, for example, $\mathrm{F}(1,30)=12.81, p=0.001$ (two way ANOVA). Post hoc Bonferroni tests confirmed significant increase in $\mathrm{W}$ and decrease in SWS within genotypes (Figure 6b). The increase in $\mathrm{W}$ driven by the motivation test was greater in $\mathrm{H} 3 \mathrm{R}-/$ - than in $\mathrm{H} 3 \mathrm{R}+/+$ mice, associated with a more pronounced decrease in SWS and PS (Figure 6b), observations further confirmed by comparisons of the net sleep- 
a

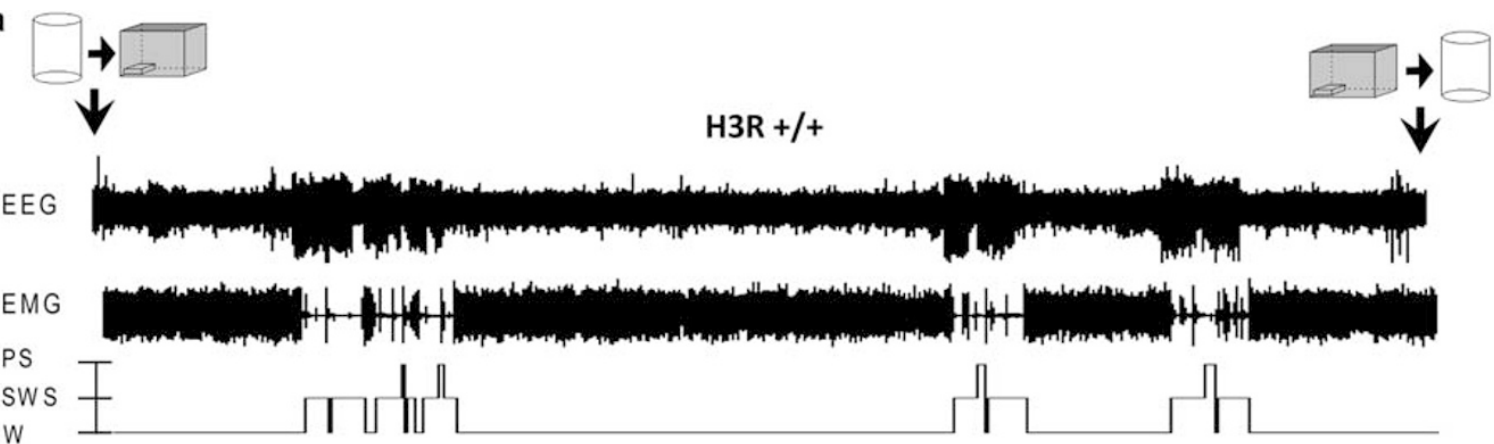

$\boldsymbol{V}$ H3R -/-
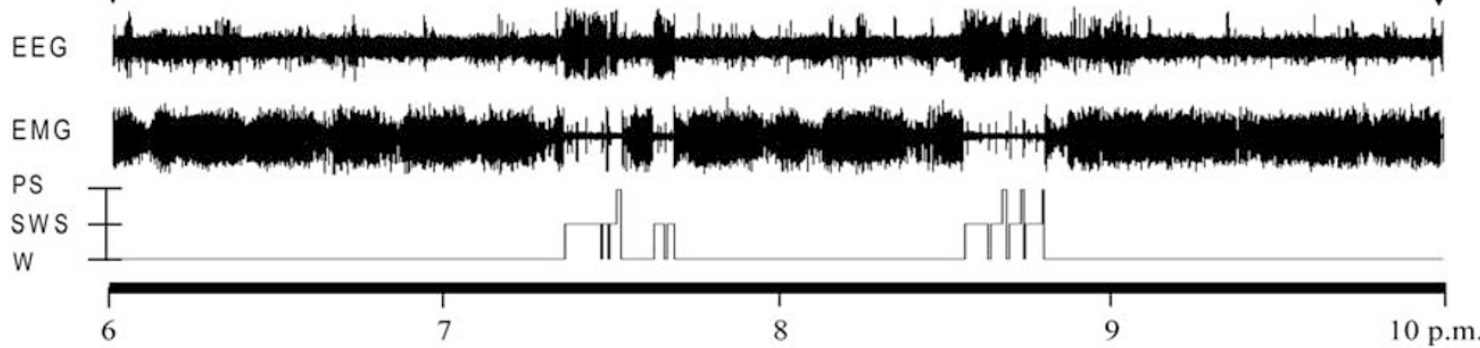

b

W

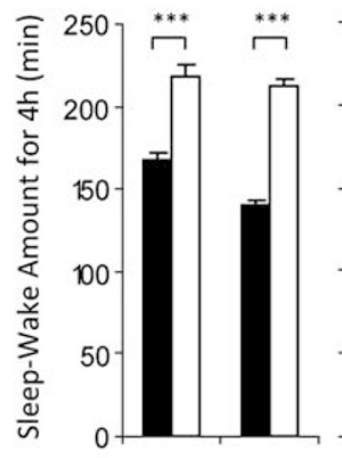

$\mathrm{H} 3 \mathrm{R}+1+-1-$
SWS

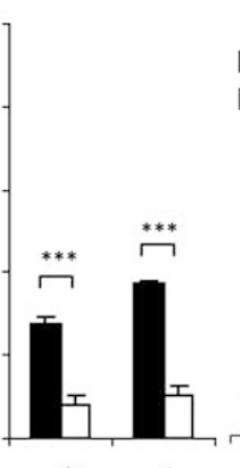

$+1+\quad-1-$
PS

Control

Change

Figure 4 Effects of an environmental change on the sleep-wake states in $\mathrm{H} 3 \mathrm{R}+/+$ and $\mathrm{H} 3 \mathrm{R}-/-$ mice. a, examples of polygraphic recording and corresponding hypnograms showing the effects of an environmental change (6-10p.m.) on cortical EEG, EMG and sleep-wake cycle. b, mean values ( \pm SEM in min) of each sleep-wake stage during the $4 \mathrm{~h}$ stay in the new environment, compared with the own baseline values of each genotype. $c$, mean net sleep-wake changes ( \pm SEM) during the test, relative to the baseline values of each genotype. Note I) a significant increase in waking (W) and decrease in slow wave sleep (SWS) and paradoxical sleep (PS) in both genotypes compared with their own baseline values (b); 2) a larger increase in $W$ and greater decrease in SWS and in PS in H3R - I - than in H3R $+1+$ mice (c). $n=22$ from II pairs of animals, ${ }^{\circ} p>0.05,{ }^{*} p<0.05$; *** $p<0.01$; **** $p<0.00 \mathrm{I}$, post hoc Bonferroni test after significance in two-way ANOVA for repeated measures for b and unpaired Student's $t$-test for $c$ (two-tails).

wake changes between the two genotypes (Figure 6c). Thus, the net increase in $\mathrm{W}$ during $4 \mathrm{~h}$ was $40 \pm 4 \mathrm{~min}$ in the $\mathrm{KO}$ mice vs $16 \pm 6 \mathrm{~min}$ in the WT mice $(n=16$ from 8 pairs of mice, $p=0.0012$, Student's $t$-test), i.e., $>2.5$ fold the increase seen with WT mice. The decrease in SWS in KO mice was also $>2$ fold that of WT mice (Figure 6c). Finally, this behavioral test had no effect on PS in WT mice, but caused a significant decrease in PS in the $\mathrm{KO}$ mice, indicating again a greater impact of the motivation test on $\mathrm{H} 3 \mathrm{R}-I-$ than on WT mice (Figures $6 \mathrm{~b}$ and $\mathrm{c}$ ).

When tested between 6-10 p.m., during the awake period, both mouse genotypes responded actively to the presence of tasty food with increased W and decreased SWS and PS. The elicited sleep-wake changes were, however, not significantly different between genotypes. For $\mathrm{W}$, for example, $+17 \pm 7$ in WT $v s+14 \pm 8 \mathrm{~min}$ in KO, $n=16$ from 8 pairs of mice $[\mathrm{F}(1,30)=0.083, p=0.77$ using two way ANOVA followed by post hoc Bonferroni tests using Genotype and Experimental condition as factors].

The extended wakefulness exhibited during the three behavioral tasks in $\mathrm{H} 3-/-$ mice is also qualified here as sleep restriction, distinct from sleep deprivation in which sleep is not allowed but similar to a voluntary sleep restriction such as that driven by personal, professional or social motivations in humans (Spiegel et al, 1999, 2004). 
a
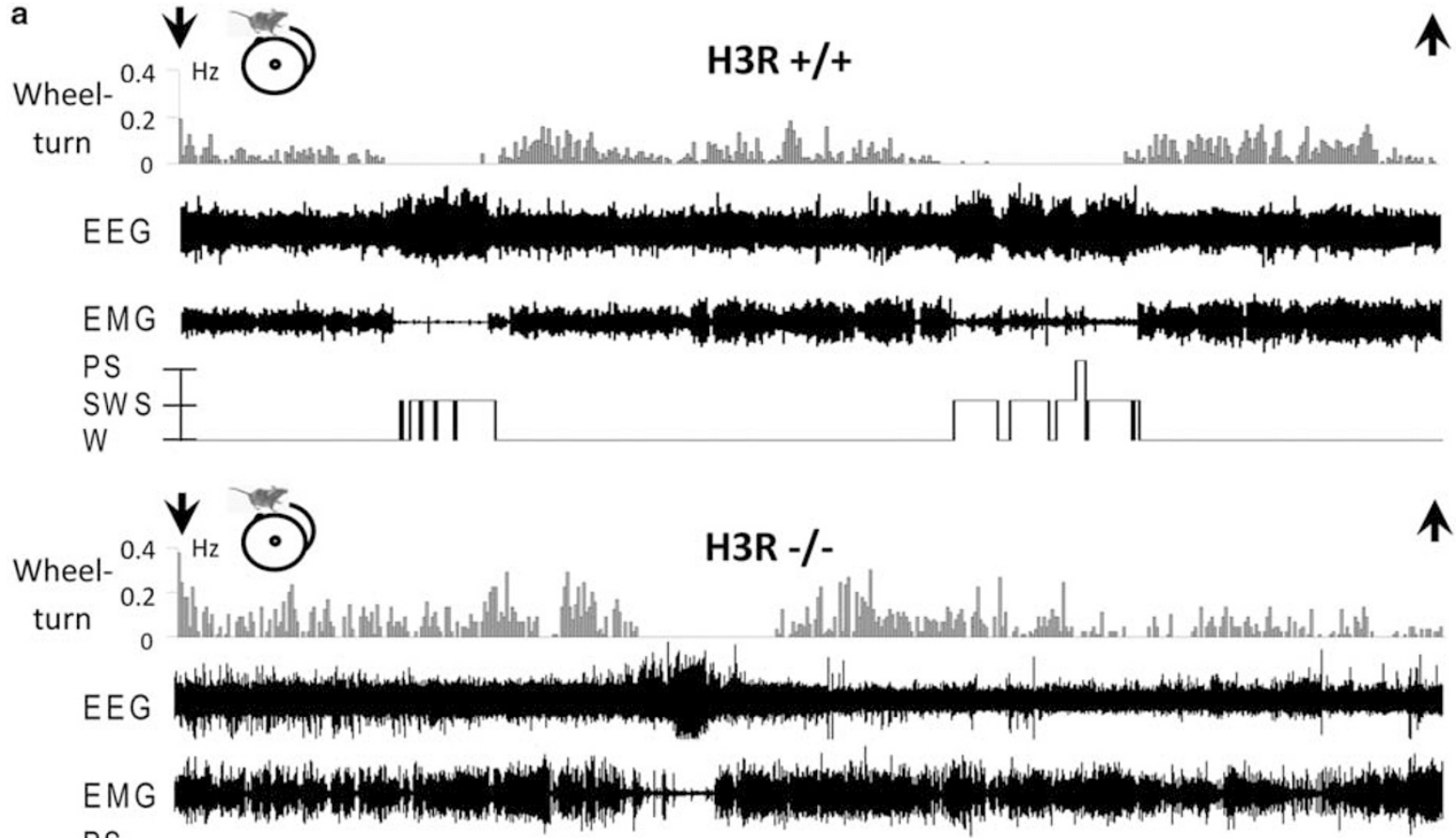

${ }_{W}^{\text {SW }}$ S I
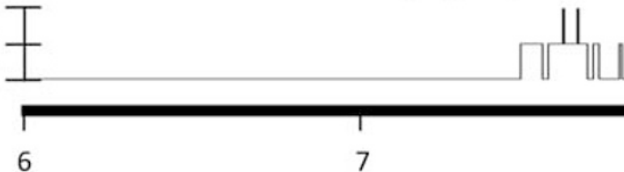

6

8

9

10 p.m.
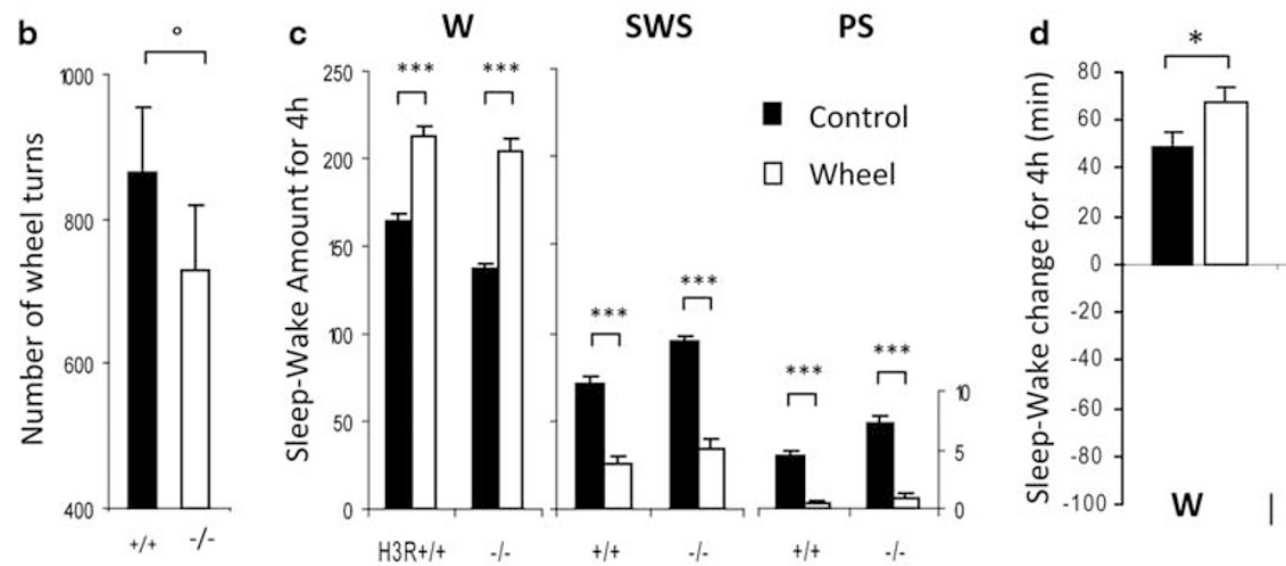

$\mathrm{H} 3 \mathrm{R}+/+$

H3R -/-

Figure 5 Effects of a wheel test on the sleep-wake states in $\mathrm{H} 3 \mathrm{R}+/+$ and $\mathrm{H} 3 \mathrm{R}-1$ - mice. a, Examples of polygraphic recording and corresponding hypnograms illustrating the effects of the wheel test (6-10 p.m.) on cortical EEG, EMG and sleep-wake cycle. b, effect of the wheel test on the locomotion (number of wheel turns). c, quantitative variations of the sleep-wake states. Mean values ( \pm SEM in min) of each sleep-wake stage during their $4 \mathrm{~h}$ stay on the wheel, compared with the own baseline values of each genotype. $d$, mean net sleep-wake changes $( \pm$ SEM) during the test, relative to the baseline values of each genotype. Note I) non significant difference between genotypes in terms of locomotion on the wheels (b); 2) a significant increase in waking (W) and decrease in slow wave sleep (SWS) and paradoxical sleep (PS) in each genotype compared with its own baseline values (c); 3 ) a greater increase in W and larger decrease in SWS and PS in H3R - I - than in H3R + I+ mice (d), $n=26$ from I 3 pairs of animals. ${ }^{\circ} p>0.05, * 0<0.05, * * * 0.01, * * * * 0<0.001$, post hoc Bonferroni test after significance in two-way ANOVA for repeated measures for $c$ and unpaired Student's $t$-test for $b$ and $d$ (two-tails).

Drug Actions on the Sleep-Wake Cycle

Ciproxifan. Two way ANOVA shows a significant interaction between Genotype and Experimental condition (ie, saline $v s$ ciproxifan) for $\mathrm{W}$ and SWS during $4 \mathrm{~h}$ after intraperitoneal injection of ciproxifan $(1 \mathrm{mg} / \mathrm{kg}, n=10$, at $10 \mathrm{a}$.m. during the light phase), a potent H3-receptor inverse agonist/antagonist (Ligneau et al, 1998): e.g., $\mathrm{F}(1,18)=$ $10.67 ; p=0.004$ for $\mathrm{W}$. In $\mathrm{H} 3 \mathrm{R}+1+$ mice, ciproxifan caused a delayed appearance of SWS ( $65 \pm 10$ min instead of $19 \pm 5 \mathrm{~min}$ seen with vehicle injection in the same animal, the same as below, $p=0.012)$ and PS $(115 \pm 15$ min instead of $39 \pm 6 \mathrm{~min}, p=0.0009$, paired $t$-tests) leading to a significant increase in time spent in W $(126 \pm 11 \mathrm{~min}$ 

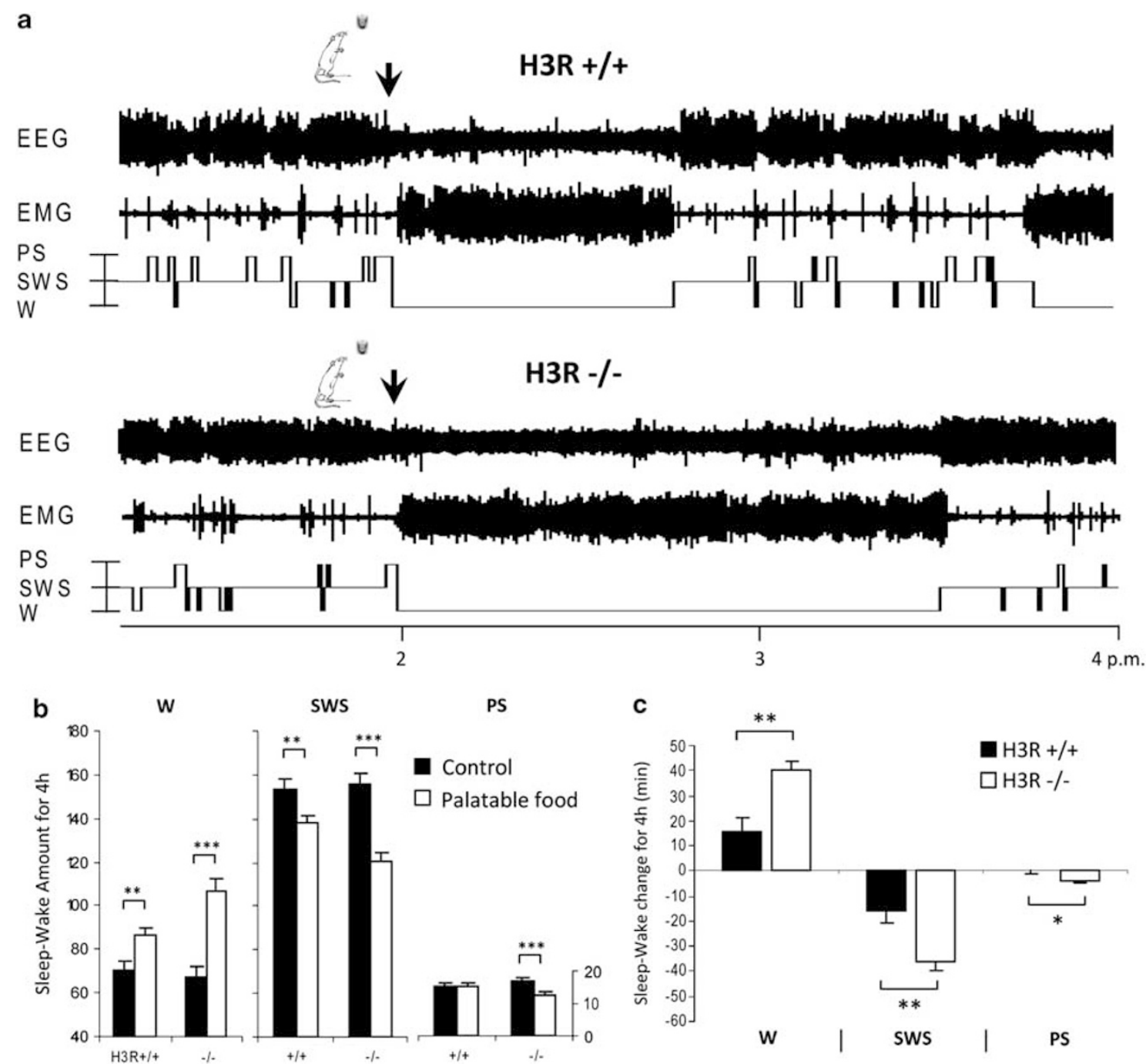

Figure 6 Effects of a motivation test using palatable food on the sleep-wake states in $\mathrm{H} 3 \mathrm{R}+/+$ and $\mathrm{H} 3 \mathrm{R}-/$ - mice. a, Examples of polygraphic recording and corresponding hypnograms showing the effects of the motivation test (2-6 p.m.) on the cortical EEG, EMG and sleep-wake cycle. b, mean values ( \pm SEM in $\mathrm{min}$ ) of each sleep-wake stage during the $4 \mathrm{~h}$ in which the palatable food was presence, compared with the own baseline values of each genotype. c, mean net sleep-wake changes ( \pm SEM in min) during the text, relative to the baseline values of each genotype. Note I) a significant increase in waking (W) and decrease in slow wave sleep (SWS) in both genotypes and a decrease in paradoxical sleep (PS) only in H3R - / - mice, compared with their own baseline values (a, b); 2) a markedly greater effects on all sleep-wake states in H3R - / - than in H3R $+/+$ mice (c). $n=16$ from 8 pairs of animals. ${ }^{\circ} p>0.05, * p<0.05, * * * 0.01$, $* * * * *<0.001$, post hoc Bonferroni test after significance in two-way ANOVA for repeated measures for $b$ and unpaired Student's t-test for c (two-tails).

instead of $80 \pm 4$ min during the first $4 \mathrm{~h}$ recordings after dosing, $p<0.001$, Bonferroni tests, Figure $7 \mathrm{~b}$ ) associated with a significant decrease in SWS and a non significant decrease in PS (Figure 7b).

In contrast, the same injection of ciproxifan in $\mathrm{H} 3 \mathrm{R}-/-$ mice had no effect on either the latency to sleep (SWS or PS) or time spent in W, SWS and PS as compared with vehicle injection in the same animals (eg $77 \pm 5$ min spent in $\mathrm{W} v \mathrm{~s}$ $73 \pm 4 \mathrm{~min}$ in control, $n=10, p>0.05$, Bonferroni tests, Figure $7 \mathrm{~b}$ ). The absence of effect of ciproxifan on $\mathrm{W}$ and SWS in the H3R-I- mice was further confirmed, by comparison of the net changes of W and SWS during the $4 \mathrm{~h}$ after ciproxifan dosing between the two genotypes (Figure 7c). At the dose used, ciproxifan had no clear effect on the amount of PS during $4 \mathrm{~h}$ in either genotype (Figure $7 \mathrm{~b}$ and $\mathrm{c}$ ). These data unambiguously indicate the functional invalidation of H3-receptor and, together with PCR-genotyping, validate our animal model.

Triprolidine. Two way ANOVA indicates a significant effect of genotype on SWS $4 \mathrm{~h}$ after intraperitoneal injection of triprolidine $(5 \mathrm{mg} / \mathrm{kg}$, at $8 \mathrm{p} . \mathrm{m}$. dark phase), a HA H1-receptor antagonist (Yanai et al, 1990; McCormick and Williamson, 1991): $\mathrm{F}(1,100)=13.83 p=0.0003$. In the WT mice, the effects lasted nearly $4 \mathrm{~h}$ with notably a significant increase in SWS at the second hour post injection $(n=14$, Figure $8 \mathrm{~b}$ ). However, the total sleep-wake amounts during 
a

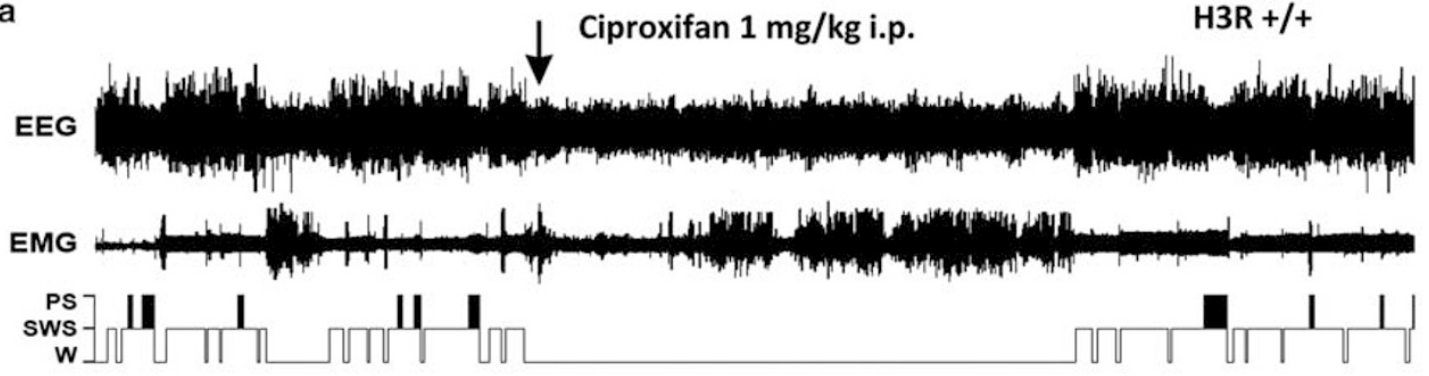

H3R -/-

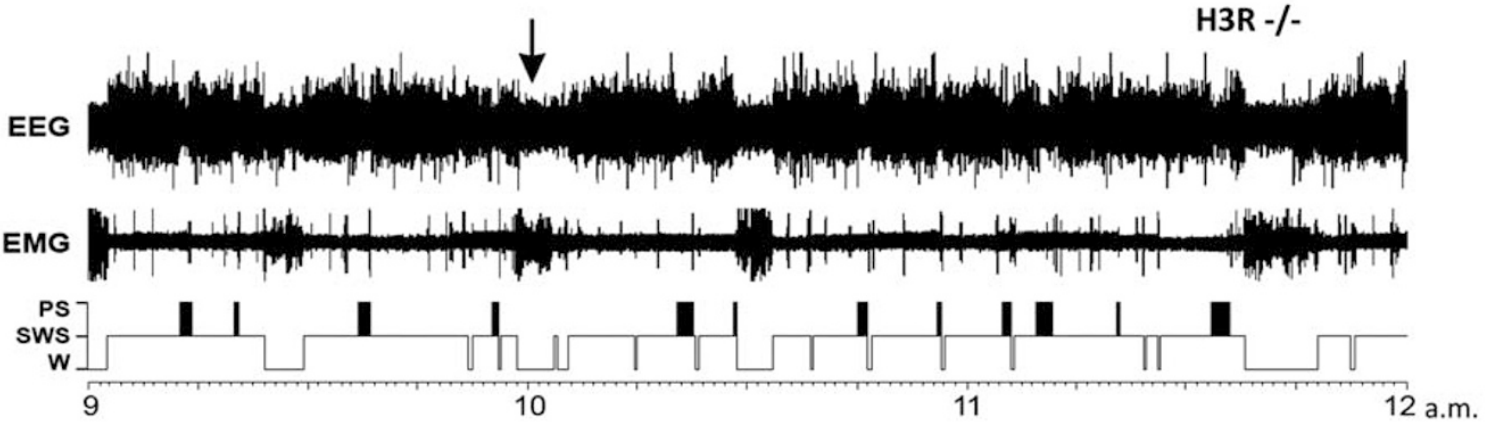

b

W

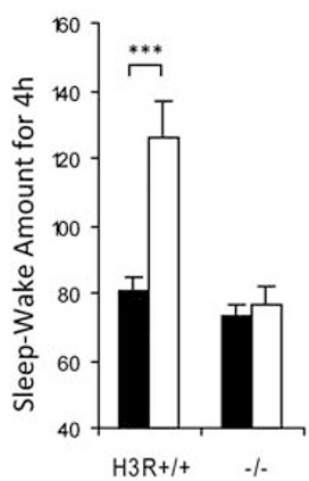

SWS

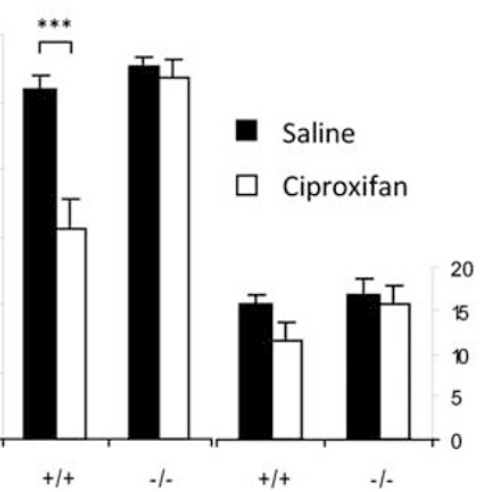

C

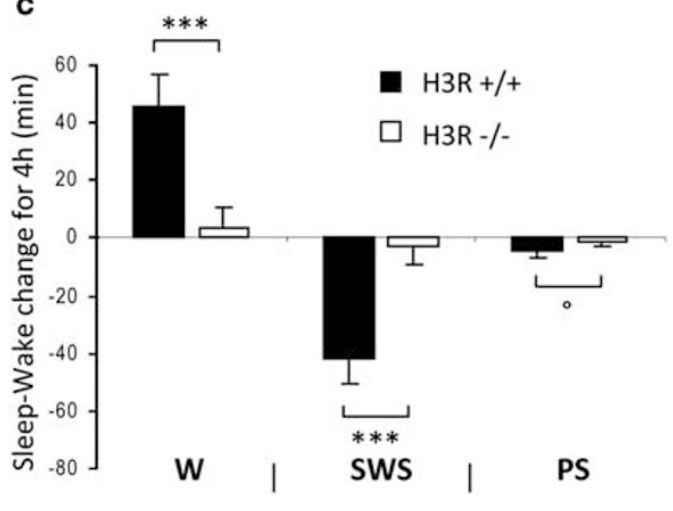

Figure 7 Effects of ciproxifan a $\mathrm{H} 3$-receptor inverse agonist, on the sleep-wake states in $\mathrm{H} 3 \mathrm{R}+/+$ and $\mathrm{H} 3 \mathrm{R}-/$ - mice. a, Examples of polygraphic recording and corresponding hypnograms showing the effects of intraperitoneal injection of ciproxifan on cortical EEG and EMG and sleep-wake cycle. b, Mean values ( \pm SEM in $\mathrm{min}$ ) of each sleep-wake stage after saline or ciproxifan injection in both genotypes. c, mean net sleep-wake changes ( \pm SEM in $\mathrm{min}$ ) relative to the baseline values of each genotype. Note in $\mathrm{H} 3 \mathrm{R}+/+$ mice, but not in $\mathrm{H} 3 \mathrm{R}-/$ - mice, that ciproxifan elicited a significant increase in waking (W) and decrease in slow wave sleep (SWS), $n=10$ for each genotype, ${ }^{\circ} p>0.05,{ }^{*} p<0.05, * * p<0.01$, **** $p<0.00$ I, post hoc Bonferroni test after significance in two-way ANOVA for repeated measures for b and unpaired Student's t-test for c (two-tails).

the $4 \mathrm{~h}$ post injection were not significantly different between vehicle and drug injections (Figures $8 \mathrm{a}$ and $\mathrm{b}$ ), indicating a rapid recovery within $4 \mathrm{~h}$. PS remained unchanged after dosing.

In $\mathrm{H} 3 \mathrm{R}-/-$ mice, the same injection of triprolidine $(n=14)$ constantly increased SWS at the expense of $\mathrm{W}$ during the $4 \mathrm{~h}$ post injection, as shown by the hourly cumulated SWS increase over the vehicle data (Figures $8 \mathrm{a}$ and b). This led to a significant increase in SWS for the whole $4 \mathrm{~h}$ period, an effect significantly different from that seen in the WT mice (Bonferroni tests, Figure 8b), Thus, triprolidine induced a greater and longer lasting effect in the KO than in WT mice, as further confirmed by direct comparisons of the net sleep-wake changes showing a significant difference for both $\mathrm{W}$ and SWS between genotypes. PS remained unchanged (Figure 8c).
(S)- $\alpha$-fluoromethylhistidine $(\alpha-F M H)$. As previously reported in mice (Parmentier et al, 2002), rats (Kiyono et al, 1985; Monti et al, 1988) and cats (Lin et al, 1988), intraperitoneal injection of $\alpha-\mathrm{FMH}$ (a specific inhibitor of histidine decarboxylase, the HA-synthesizing enzyme, $50 \mathrm{mg} / \mathrm{kg}$ ) in WT mice at 4 p.m. resulted in a progressively developing and significant decrease in $\mathrm{W}$ and an increase in both SWS and PS ( $n=18$, Figures $9 \mathrm{a}$ and b). The effects became significant at the 8 th $\mathrm{h}$ after dosing for $\mathrm{W}$ and 5 th $\mathrm{h}$ for SWS and PS and were maintained for 6-10 more hours for all the sleep-wake states.

Compared with those in WT mice, the effects of $\alpha-\mathrm{FMH}$ in $\mathrm{H} 3 \mathrm{R}-/$ - mice were characterized by 1) a more prompt onset: W and SWS were significantly changed as early as the 5th and 4th h post injection; 2) larger changes of $\mathrm{W}$ and SWS, starting at $14 \mathrm{~h}$ post dosing even though the difference 

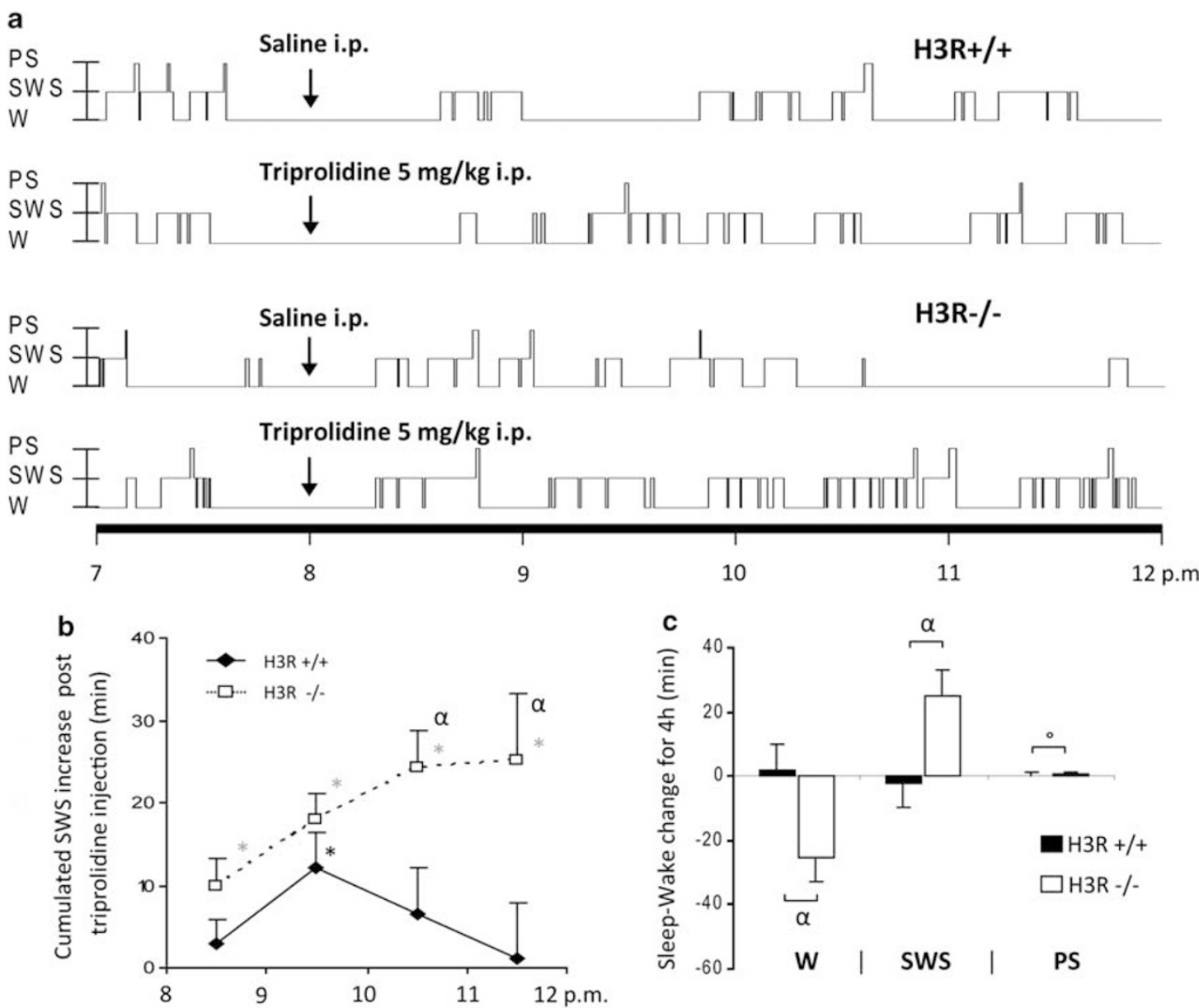

Figure 8 Effects of triprolidine, a HI-receptor antagonist, on the sleep-wake states in $\mathrm{H} 3 \mathrm{R}+/+$ and $\mathrm{H} 3 \mathrm{R}-/$ - mice. a, Examples of hypnograms showing the effects of intraperitoneal injection of triprolidine on the sleep-wake cycle. b, hourly cumulated increase in slow wave sleep (SWS) post triprolidine injection, relative to saline injection (baseline 0), comparison using post hoc Bonferroni test after significance in a two-way ANOVA for repeated measures $c$, mean net sleep-wake changes ( \pm SEM in min) relative to the baseline values of each genotype obtained with saline injection, comparison using unpaired Student's t-test (two-tails). Note that tiprolidine induced an increase in SWS and decrease in W in both genotypes (a), but the effects are significantly greater in $\mathrm{H} 3 \mathrm{R}-1$ - than in $\mathrm{H} 3 \mathrm{R}+1+$ mice in that I) the SWS increase was evidenced each hour during $4 \mathrm{~h}$ in the KO mice instead of only the second hour in the WT mice (b); 2) there is a significant difference between genotypes in terms of W and SWS changes (c). $n=14$ for each genotype, ${ }^{\circ} p>0.05$; $* p<0.05$; $* * * 0.0$ I compared with values of saline injection in the same animals; ${ }^{\alpha} p<0.05$ compared with values of $\mathrm{H} 3+$ I + mice.

remained non-significant at this time parameter (Figure 7a) but became pronounced and significant at $24 \mathrm{~h}$ post dosing (ANOVA, Figure $7 \mathrm{~b}$ ) and 3) a longer-lasting action on the sleep-wake states. Thus, for the $24 \mathrm{~h}$ period post-dosing, two way ANOVA indicates a significant interaction between Genotype and Experimental condition (ie, saline $v s \alpha$-FMH) for $\mathrm{W}: \mathrm{F}(1,33)=6.112, p=0.019$ and SWS: $\mathrm{F}(1,33)=6.108$, $p=0.019$. Moreover, post hoc Bonferroni tests within genotypes indicate that the effects on W and SWS remained significantly modified in $\mathrm{H} 3 \mathrm{R}-/$ - mice compared with their own control whereas those in the WT mice had returned to control levels (Figure 9b). Finally, as in other behavioral and pharmacological tests, the impact of the genotype on the effects of $\alpha$-FMH is further confirmed by a significant difference between the two genotypes regarding the effects on both $\mathrm{W}$ and SWS during $24 \mathrm{~h}$ post dosing (Figure 9c).

\section{DISCUSSION}

The present study was designed to determine the sleep-wake consequences of long-term increased histamine (HA) neurotransmission using wild-type (WT) and H3-receptor knockout $(\mathrm{H} 3 \mathrm{R}-/-)$ mouse littermates, a promising experimental model for sleep-wake disorders. We found that $\mathrm{H} 3 \mathrm{R}-/-$ mice were rich in phenotypes, characterized notably by a wide-range of sleep-wake alterations. On the one hand, immediately after lights-off, they showed deficient wakefulness (W) and signs of sleep deterioration, such as pronounced sleep fragmentation and reduced cortical slow activity during slow wave sleep (SWS). On the other hand, they displayed signs of enhanced vigilance, i.e., increased cortical EEG $\theta$ power during spontaneous $\mathrm{W}$ and an exaggerated increase in $\mathrm{W}$ in response to behavioral challenges, including an environmental change, locomotion 

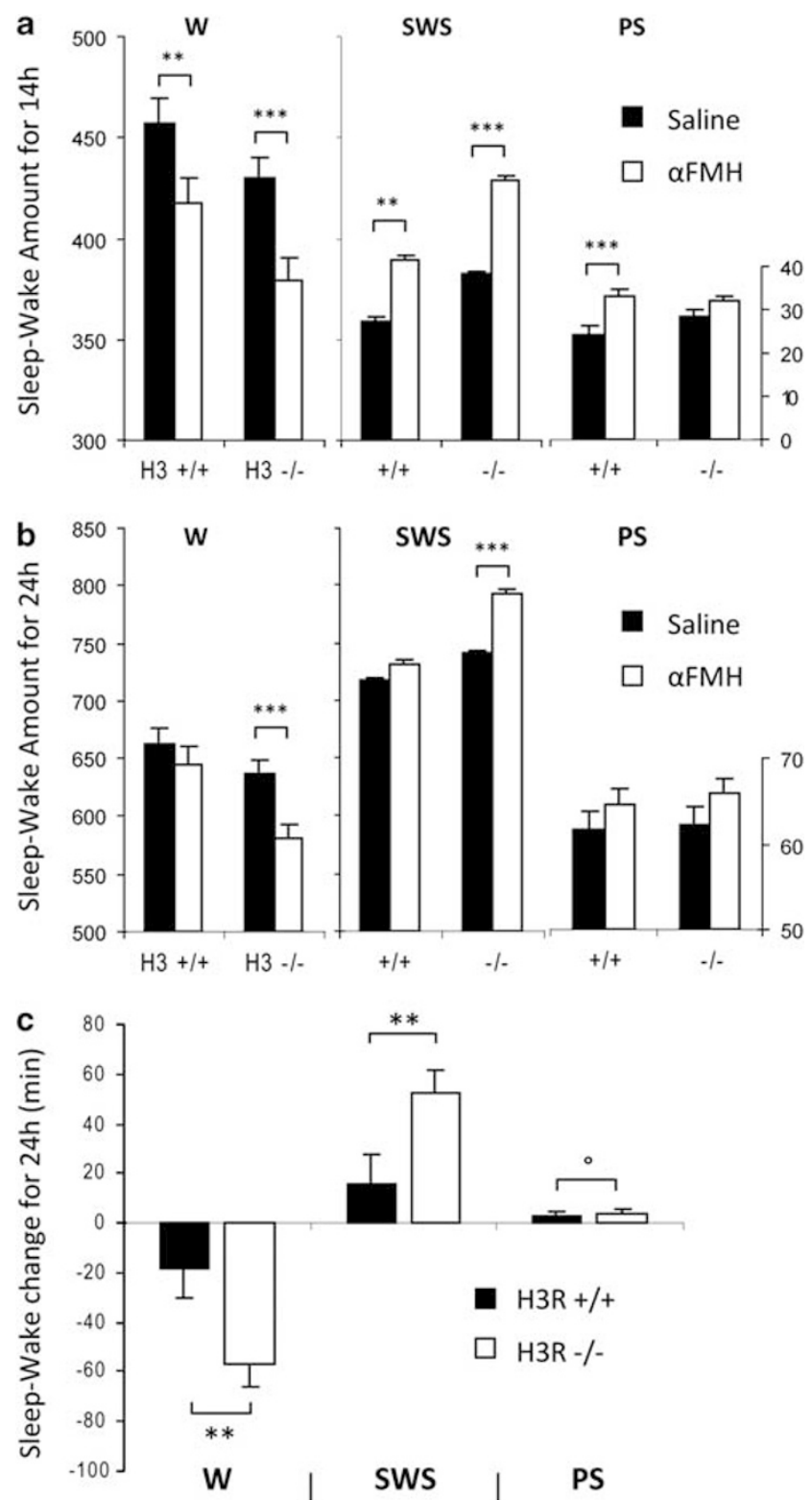

Figure 9 Effects of $\alpha$-FMH, an inhibitor of histamine synthesis, on the sleep-wake states in $\mathrm{H} 3 \mathrm{R}+1+$ and $\mathrm{H} 3 \mathrm{R}-/$ - mice. $A, B$, mean values ( \pm SEM in $\mathrm{min}$ ) of each sleep-wake stage during $14 \mathrm{~h} \mathrm{(a)} \mathrm{or} 24 \mathrm{~h}$ (b) after injection of saline or $\alpha-F M H ~(50 \mathrm{mg} / \mathrm{kg}$, i.p., at 4 p.m.). c, mean net sleepwake changes during $24 \mathrm{~h}$ post $\alpha-F M H$ injection ( \pm SEM in min), relative to the baseline values of each genotype obtained with saline injection. Note that I) $\alpha-F M H$ induced an increase in SWS and decrease in W in both genotypes during $14 \mathrm{~h}$ post injection (a, comparison using paired $t$-test, two-tails). The effects appear larger in $\mathrm{H} 3 \mathrm{R}-1$ - mice than in $\mathrm{H} 3 \mathrm{R}+\mathrm{I}+$ mice, but the difference is not yet statistically significant at this time parameter (a, two way ANOVA); 2) at $24 \mathrm{~h}$ post-injection (b), the difference becomes significant between genotypes: the decrease in $\mathrm{W}$ and increase in SWS remain significant in HR3 - / - mice but not in $\mathrm{H} 3 \mathrm{R}+$ I+ mice (b, post hoc Bonferroni tests after significance in two-way ANOVA for repeated measures) and that 3 ) there is a significant difference between genotypes in terms of the net changes of $W$ and SWS (c, unpaired Student's $t$-test, two-tails). $n=18$ for each genotype, ${ }^{\circ} p>0.05,{ }^{*} p<0.05$, *** $p<0.0$ I, ***** $p<0.00$ I.

and motivation tests. This is the first study, to the best of our knowledge, in which the sleep-wake phenotypes of $\mathrm{H} 3 \mathrm{R}-\mathrm{I}-$ mice were clearly identified. The questions raised here are how the deletion of the H3-receptor gene resulted in such apparently 'contradictory' phenotypes, how they can be interpreted in light of the altered HA neurotransmission of this mouse model and whether they are consequences of long-term enhancement of the HA arousal system.

\section{Wake Deficiency in H3-Receptor Knockout Mice, Consequence of Decreased Histamine Cell Activity and Desensitization of Postsynaptic Histamine Receptors?}

HA neurons are currently thought to promote W. H3receptor is widespread distributed in the brain on both HA and non-HA neurons and plays a role of auto- and heteroreceptor. As auto-receptor, it controls the activity of HA neurons and the release and synthesis of HA through negative feedback (Reviewed in Schwartz et al, 1991; Haas et al, 2008. See Figure 10a). In H3R - / - mice, abolition of negative feedback results in enhanced brain HA turnover, manifested as a decrease in $\mathrm{HA}$ and a general increase in tele-methylhistamine ( $t$-MHA), the direct metabolite of the amine (Takahashi et al, 2002; Toyota et al, 2002). One would therefore expect such an enhancement to promote waking, while, in contrast, we found that $\mathrm{H} 3-\mathrm{KO}$ mice exhibited under baseline conditions marked wake deficiency, sleep fragmentation and impaired EEG slow activity during SWS, phenotypes reminiscent of those seen with histidine-decarboxylase (HDC) $-I-$ mice (Parmentier et al, 2002) which lack HA synthesis and neurotransmission.

First, could the decrease in HA, seen in $\mathrm{H} 3 \mathrm{R}-/-$ mice (Takahashi et al, 2002; Toyota et al, 2002), cause such wake deficient phenotypes? A down-regulation of HA synthesis or/and an exhausted stock resulted from the over-release of HA could then be responsible. However, this interpretation appears to be unlikely because the decreased $\mathrm{HA}$ is accompanied by a marked increase in t-MHA in many brain regions - characteristics of an overuse of the amine and an up-regulated HA turnover rather than a down regulation. In support of this, we found that presynaptic inhibition of the HA synthesis by $\alpha$-FMH (specific inhibitor of HDC) or postsynaptic blockade using triprolidine (H1-receptor antagonist), both induced a greater and longer-lasting increase in SWS in the KO than the WT mice, suggesting an up-regulated synthesis and release of $\mathrm{HA}$ in $\mathrm{H} 3 \mathrm{R}-I-$ mice.

Another hypothesis would be that this wake deficiency results from a chronic alteration of other neural systems mediated by H3-heteroreceptors which control the release and synthesis of some neuropeptides and neurotransmitters such as serotonin, dopamine, noradrenalin and acetylcholine. Like HA, these neurotransmitters are also components of the brain ascending activating systems controlling different behavioral and cognitive aspects of wakefulness. Nevertheless, the brain levels of the afore mentioned monoamines are unchanged in $\mathrm{H} 3 \mathrm{R}-/-$ mice (Toyota et al, 2002; Nuutinen et al, 2011) in contrast to a clearly altered HA turnover. They could not, therefore, be accountable for the observed wake deficiency. It remains, however, to determine whether the cholinergic transmission is altered in $\mathrm{H} 3 \mathrm{R}-/-$ mice. The cholinergic system constitutes a privileged target for HA neurons and the 


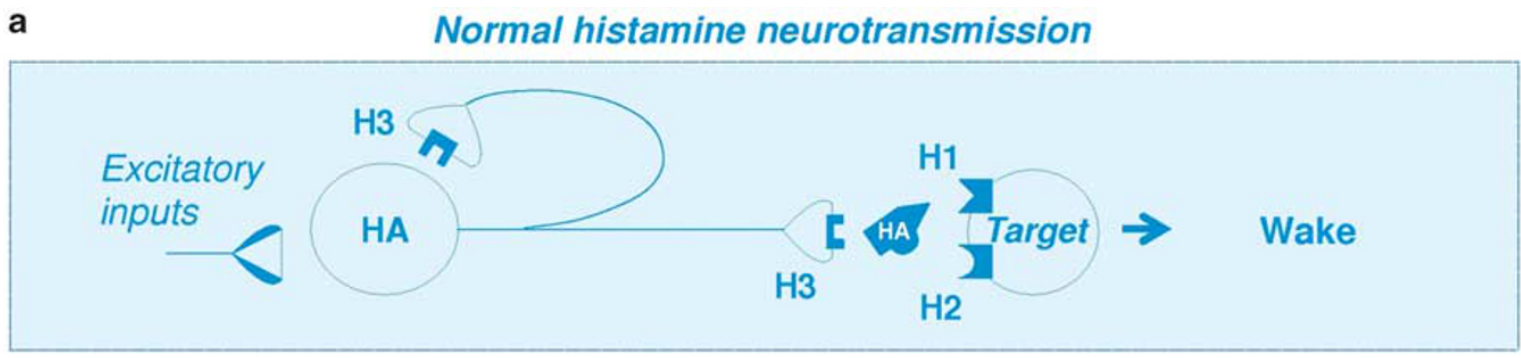

b H3-receptor deletion under baseline conditions

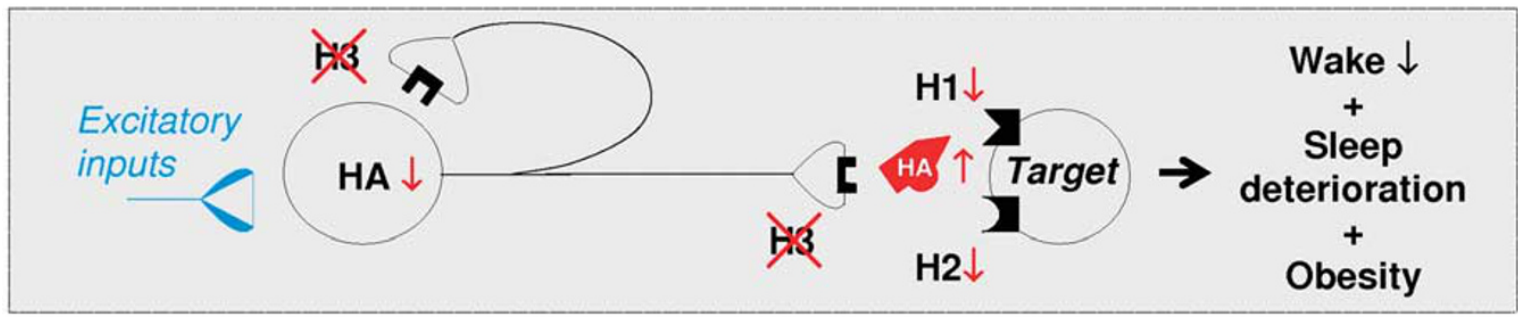

C

H3-receptor deletion facing behavioral challenges

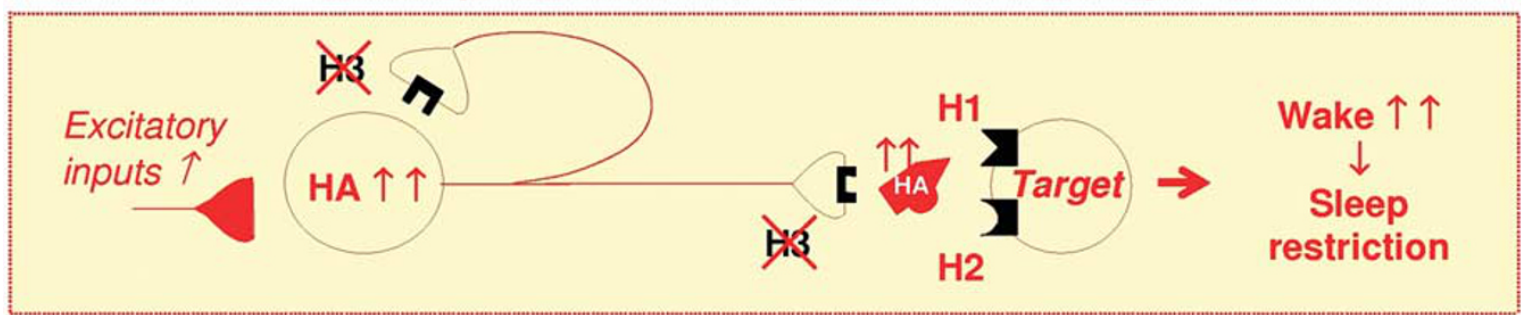

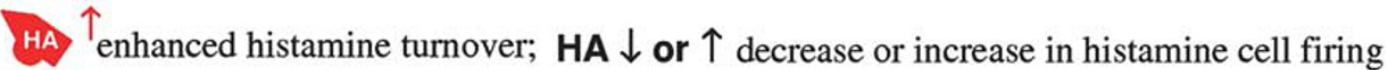

Figure 10 Schematic representation of our hypothesis on the consequences of H3-receptor deletion on histamine neurotransmission, sleep-wake states and metabolic outputs in $\mathrm{H} 3$-receptor knockout mice. Only presynaptic $\mathrm{H} 3$-autoreceptor is considered here. a, normal histamine (HA) neurotransmission promoting wake. Postsynaptic $\mathrm{HI}$ and $\mathrm{H} 2$ receptors are responsible for the arousal effect of $\mathrm{HA}$ whereas presynaptic $\mathrm{H} 3$-receptors are involved by a negative feedback on HA neurons. b. Under baseline conditions, the constantly-enhanced HA neurotransmission in H3-receptor knockout mice would finally produce by homeostatic processes a decrease in $\mathrm{HA}$ neuronal activity and desensitization of $\mathrm{HI}$ and $\mathrm{H} 2$ postsynaptic receptors, causing wake deficit, sleep deterioration and phenotypes of obesity. c. Facing behavioral challenges and consequently enhanced excitatory inputs, the absence of negative feedback results in an over activity of HA neurons which would overcome the postsynaptic defect, causing exaggerated wake responses and thus sleep restriction. Blue, black or red color signifies respectively normal, impaired or enhanced activity. $\downarrow$ down regulation; $\uparrow$ up regulation.

interaction between the two systems plays a major role in the brain network responsible for cortical arousal and cognition (Lin et al, 1996; Reviewed in Lin, 2000; Passani et al, 2004). The cholinergic system certainly could be involved in the procognitive effect of H3-receptor inverse agonists/antagonists (Reviewed in Lin et al, 2011a) but does not seem to be directly responsible for the sleep-wake phenotypes seen in $\mathrm{H} 3 \mathrm{R}-1-$ mice because $\mathrm{H} 3$-receptor mediated arousal appears clearly HA-dependent. Indeed, ciproxifan, a H3-receptor inverse agonist/antagonist enhanced waking in WT mice but had no effect in either $\mathrm{H} 3 \mathrm{R}-I-$ mice as demonstrated in the present study, or in $\mathrm{HDC}-/$ - or H1R - / - mice (Parmentier et al, 2002; 2007). Similarly, thioperamide, another inverse agonist had no effect in another H3R $-/$ - mouse strain (Toyota et al, 2002).

We therefore suggest that acute blockade of H3-receptors and removal of negative feedback would cause an over activity of HA neurons (Schwartz et al, 1991; Vanni-Merci et al. 2003; Lin et al, 2011a) whereas chronic loss of HA auto-regulation would, through homeostatic processes (Turrigiano, 2008), lead to a decrease in HA neuronal firing, contributing to the wake deficit of $\mathrm{H} 3 \mathrm{R}-/-$ mice. Moreover, due to the constant and intense release of HA, postsynaptic receptors would finally lose their responsiveness to HA. Because H1- and H2-receptors are responsible for histaminergic arousal (Schwartz et al, 1991; Lin, 2000; Brown et al, 2001; Haas et al, 2008; Figure 10a), their desensitization would result in deficient arousal under baseline conditions (Figure 10b), phenotypes similar to, or even more severe than, those of KO mice lacking either HA neurotransmission or postsynaptic receptors (Inoue et al, 1996; Parmentier et al, 2002; Masaki et al, 2004; Masaki and Yoshimatsu, 2006).

This desensitization appears to occur towards agonist, i.e., endogenous HA itself and apparently not towards 
antagonist. Repeated receptor activation by agonists would instead cause high sensitization to antagonists as suggested in this study by a larger SWS-increasing effect of triprolidine in $\mathrm{H} 3 \mathrm{R}-/-$ mice. In support of such a desensitization hypothesis, the H1-receptor is down-regulated in $\mathrm{H} 3 \mathrm{R}-/-$ mice as indicated by a decrease in binding sites in the hypothalamus (Takahashi et al, 2002; Tokita et al, 2006). Further studies are needed to determine if this down regulation extends to all postsynaptic HAreceptors and other brain areas. Investigations combined with functional approaches are necessary to assess whether this desensitization occurs at the level of gene transcript or/ and receptor affinity and excitability.

Increased Vigilance in H3-Receptor Knockout Mice and Enhanced Histamine Neuronal Activity and Neurotransmission Facing Behavioral Challenges

A decreased HA neuronal activity and desensitization of postsynaptic HA receptors seemed pronounced in that $\mathrm{H} 3 \mathrm{R}-/-$ mice exhibited an impaired maintenance of brain arousal under baseline conditions. This situation was reversed, however, when facing behavioral challenges which increased excitatory inputs to HA neurons (Figure 10c). In fact, H3R - / - mice responded to behavioral challenges with an exaggerated increase in wakefulness. They showed a more extensive wakefulness in a new environment and were more alert on a wheel even though their running activity was below the normal level. Moreover, they were more motivated, making greater efforts to obtain difficult-toreach palatable food and, as a result, remained highly awake: $>2.5$ fold of the wake increase of WT littermates. This occurred at times when they were normally most sleepy. The extended wakefulness demonstrated here facing behavioral tasks is reminiscent of human voluntary sleep restriction. Finally, although quantitatively deficient after lights-off, their waking state during darkness was associated with a higher $\theta$ rhythm. This indicates higher cortical activation and alertness, which would allow $\mathrm{H} 3 \mathrm{R}-/-$ mice to respond to behavioral challenges with sustained waking. The fact that $\mathrm{H} 3 \mathrm{R}-/-$ mice show enhanced spatial learning and memory (Rizk et al, 2004) also indicates their improved behavioral performance.

These signs of enhanced vigilance contrasting with the somnolence and wake deficiency of $\mathrm{HDC}-/-$ mice in a new environment (Parmentier et al, 2002) are consistent with the proposed role for HA in promoting wakefulness and the functions of $\mathrm{H} 3$-receptors in HA neurotransmission. Pharmacological enhancement of histaminergic neuronal activity by acute blockade of H3-receptors using inverse agonists, prolongs wake duration, enhances cortical fast activities (and $\theta$ rhythm in mice) during waking and improves cognitive outputs in several species (Lin et al, 1990, 2008, 2011a; Monti, 1993; Ligneau et al, 1998, 2006, 2007; Barbier et al, 2004; Bonaventure et al, 2007; Parmentier et al, 2007; Esbenshade et al, 2008; Hajos et al, 2008; Guo et al, 2009).

Thus, these data further support the role of HA in wake maintenance during behavioral challenges. Even though HA's over-release would, under baseline conditions, damage histaminergic neuronal activity and neurotransmission leading to wake defect, under behavioral stimuli which enhance excitatory inputs to HA neurons (Sakai et al, 1990; Haas et al, 2008), the absence of negative feedback would, nevertheless, allow these neurons to fire in an exaggerated manner, thus overcoming the postsynaptic defect and ultimately leading to improved vigilance and behavioral performance (Figure 10c). Additional experimental data in $\mathrm{H} 3 \mathrm{R}-/-$ mice, notably HA release in vivo and HA neuronal activity during behavioral tasks, would certainly be very valuable for the validation of this hypothesis (Figure 10).

\section{H3-receptor Knockout Mouse, a Murine Model of Sleep Restriction?}

The sleep-wake characteristics demonstrated here and the previously reported obesity phenotypes of $\mathrm{H} 3 \mathrm{R}-/$ - mice, e.g., increased food intake and decreased glucose tolerance/ insulin sensitivity (Takahashi et al, 2002) are very similar to the metabolic and sleep-wake consequences seen with voluntary sleep restriction in humans, an increasing phenomenon in our society with major impact on public health (Spiegel et al, 1999, 2004).

This leads us to suggest $\mathrm{H} 3 \mathrm{R}-/-$ mice as an animal model of voluntary sleep restriction. Hence, in consistence with the proposed role for HA and when facing diverse tasks or behavioral challenges (motivation, eg), the absence of negative feedback on HA neurons results in a response with overly extended waking akin to voluntary sleep restriction in humans (Figure 10c). However, as a 'price to pay' for such a 'high performance', constantly intensified brain arousal would lead to exhaustion of the HA arousal system, i.e., impaired cell activity and neurotransmission under baseline conditions, causing wake deficit, sleep deterioration and disturbances leading to increased adiposity and obesity (Takahashi et al, 2002)(Figure 10c). Other specific behavioral studies are needed in order to assess whether such a long-term enhancement of the HA system produces any cognitive output relevant to human voluntary sleep restriction.

Whereas this model remains to be further characterized using inducible $\mathrm{KO}$ mice in which the immediate effects and time course following $\mathrm{H} 3$-receptor deletion could be evaluated, H3R - I- mice already appear as a useful experimental model for determining the relationship between sleep restriction and metabolism. It would also allow investigation of the impact of sleep therapy on metabolic disorders, such as obesity, a major problem of public health.

Taken together, we suggest that chronic enhancement of an arousal system, like the histaminergic system, would eventually produce dysfunction of the arousal system per se, leading not only to baseline wake deficiency and sleep restriction facing behavioral tasks, but also to behavioral and metabolic disorders similar to the consequences of voluntary sleep restriction in humans. It is expected that normalizing the arousal systems would restore sleep-wake quantity and quality, thus improving the metabolic parameters and the affected functions.

\section{ACKNOWLEDGEMENTS}

This work was supported by INSERM-U628, Claude Bernard University and the European Community, Fifth 
Framework Program Grant QLRT-2001-00826 (for J.S.L.). We thank M.C. Dalin and M. Gilot for their involvement in the early stage of this study, Institut Franco-Chinois for fellowships to M Zhang and RX Guo, Dr L Seugnet for useful discussion and critical lecture of the manuscript and G. Debilly for advice on statistics. Preliminary results were presented at the 2008 annual meeting of Société Française de Recherche et Médecine du Sommeil (SFRMS) and the 20th Congress of the European Sleep Research Society (ESRS) and published in abstract form (Gondard et al, 2008 and 2010).

\section{DISCLOSURE}

The authors declare no conflict of interest.

\section{REFERENCES}

Abe H, Honma S, Ohtsu H, Honma K (2004). Circadian rhythms in behavior and clock gene expressions in the brain of mice lacking histidine decarboxylase. Brain Res Mol Brain Res 124: 178-187.

Anaclet C, Parmentier R, Ouk K, Guidon G, Buda C, Sastre JP et al (2009). Orexin/hypocretin and histamine: distinct roles in the control of wakefulness demonstrated using knock-out mouse models. J Neurosci 29: 14423-14438.

Arrang JM, Garbarg M, Schwartz JC (1983). Auto-inhibition of brain histamine release mediated by a novel class (H3) of histamine receptor. Nature 302: 832-837.

Barbier AJ, Berridge C, Dugovic C, Laposky AD, Wilson SJ, Boggs J et al (2004). Acute wake-promoting actions of JNJ-5207852, a novel, diamine-based $\mathrm{H} 3$ antagonist. $\mathrm{Br} J$ Pharmacol 143: 649-661.

Bonaventure P, Letavic M, Dugovic C, Wilson S, Aluisio L, Pudiak C et al (2007). Histamine H3 receptor antagonists: from target identification to drug leads. Biochem Pharmacol 73: 1084-1096.

Brown RE, Stevens DR, Haas HL (2001). The physiology of brain histamine. Prog Neurobiol 63: 637-672.

Esbenshade TA, Browman KE, Bitner RS, Strakhova M, Cowart MD, Brioni JD (2008). The histamine H3 receptor: an attractive target for the treatment of cognitive disorders. $\mathrm{Br}$ J Pharmacol 154: 1166-1181.

Garbarg M, Barbin G, Rodergas E, Schwartz JC (1980). Inhibition of histamine synthesis in brain by alpha-fluoromethylhistidine, a new irreversible inhibitor: in vitro and in vivo studies. J Neurochem 35: 1045-1052.

Gondard E, Anaclet A, Zhang M, Buda C, Sastre JP, Guidon G et al (2008). Sleep-wake regulation by histamine and its H3-receptors: study using knock-out mouse model. Annual meeting of Société Française de Recherche et Médicine du Sommeil (SFRMS), 2008 Lille, France.

Gondard E, Anaclet A, Zhang M, Guo RX, Buda C, Sastre JP et al (2010). Increased Histaminergic Neurotransmission and SleepWake Alterations, Study in Histamine H3-Receptor Knock-out Mice, 20th Congress of the European Sleep Research Society (ESRS), Lisbon, Portuguese. J Sleep Res 19: 571.

Guo RX, Anaclet C, Roberts JC, Parmentier R, Zhang M, Guidon G et al (2009). Differential effects of acute and repeat dosing with the H3 antagonist GSK189254 on the sleep-wake cycle and narcoleptic episodes in $\mathrm{Ox}-/$ - mice. Br J Pharmacol 157: 104-117.

Haas HL, Sergeeva OA, Selbach O (2008). Histamine in the nervous system. Physiol Rev 88: 1183-1241.
Hajos M, Siok CJ, Hoffmann WE, Li S, Kocsis B (2008). Modulation of hippocampal theta oscillation by histamine $\mathrm{H} 3$ receptors. J Pharmacol Exp Ther 324: 391-398.

Hong ST, Bang S, Paik D, Kang J, Hwang S, Jeon K et al (2006). Histamine and its receptors modulate temperature-preference behaviors in Drosophila. J Neurosci 26: 7245-7256.

Inoue I, Yanai K, Kitamura D, Taniuchi I, Kobayashi T, Niimura K et al (1996). Impaired locomotor activity and exploratory behavior in mice lacking histamine $\mathrm{H} 1$ receptors. Proc Natl Acad Sci USA 93: 13316-13320.

Jones BE (2005). From waking to sleeping: neuronal and chemical substrates. Trends Pharmacol Sci 26: 578-586.

Kiyono S, Seo ML, Shibagaki M, Watanabe T, Maeyama K, Wada H (1985). Effects of alpha-fluoromethylhistidine on sleep-waking parameters in rats. Physiol Behav 34: 615-617.

Kollonitsch J, Perkins LM, Patchett AA, Doldouras GA, Marburg S, Duggan DE et al (1978). Selective inhibitors of biosynthesis of aminergic neurotransmitters. Nature 274: 906-908.

Ligneau X, Landais L, Perrin D, Piriou J, Uguen M, Denis E et al (2007). Brain histamine and schizophrenia: potential therapeutic applications of H3-receptor inverse agonists studied with BF2.649. Biochem Pharmacol 73: 1215-1224.

Ligneau X, Lin JS, Vanni-Mercier G, Jouvet M, Muir JL, Ganellin CR et al (1998). Neurochemical and behavioral effects of ciproxifan, a potent histamine H3-receptor antagonist. J Pharmacol Exp Ther 287: 658-666.

Ligneau X, Perrin D, Landais L, Camelin JC, Calmels TP, BerrebiBertrand I et al (2006). BF2.649 [1-\{3-[3-(4-Chlorophenyl) propoxy]propyl\}piperidine, hydrochloride], a nonimidazole inverse agonist/antagonist at the human histamine $\mathrm{H} 3$ receptor: Preclinical pharmacology. J Pharmacol Exp Ther 320: 365-375.

Lin JS (2000). Brain structures and mechanisms involved in the control of cortical activation and wakefulness, with emphasis on the posterior hypothalamus and histaminergic neurons. Sleep Med Rev 4: 471-503.

Lin JS, Anaclet C, Sergeeva OA, Haas HL (2011b). The waking brain: an update. Cell Mol Life Sci 68: 2499-2512.

Lin JS, Dauvilliers Y, Arnulf I, Bastuji H, Anaclet C, Parmentier R et al (2008). An inverse agonist of histamine $\mathrm{H}(3)$ receptor improves wakefulness in narcolepsy: studies in orexin $-1-$ mice and patients. Neurobiol Dis 30: 74-83.

Lin JS, Hou Y, Sakai K, Jouvet M (1996). Histaminergic descending inputs to the mesopontine tegmentum and their role in the control of cortical activation and wakefulness in the cat. J Neurosci 16: 1523-1537.

Lin JS, Kitahama K, Fort P, Panula P, Denney RM, Jouvet M (1993). Histaminergic system in the cat hypothalamus with reference to type B monoamine oxidase. J Comp Neurol 330: 405-420.

Lin JS, Luppi PH, Salvert D, Sakai K, Jouvet M (1986). [Histamineimmunoreactive neurons in the hypothalamus of cats]. $C R$ Acad Sci III 303: 371-376.

Lin JS, Sakai K, Jouvet M (1988). Evidence for histaminergic arousal mechanisms in the hypothalamus of cat. Neuropharmacology 27: 111-122.

Lin JS, Sakai K, Vanni-Mercier G, Arrang JM, Garbarg M, Schwartz JC et al (1990). Involvement of histaminergic neurons in arousal mechanisms demonstrated with $\mathrm{H} 3$-receptor ligands in the cat. Brain Res 523: 325-330.

Lin JS, Sergeeva OA, Haas HL (2011a). Histamine H3 receptors and sleep-wake regulation. J Pharmacol Exp Therap 336: 17-23.

Maeyama K, Watanabe T, Taguchi Y, Yamatodani A, Wada $\mathrm{H}$ (1982). Effect of alpha-fluoromethylhistidine, a suicide inhibitor of histidine decarboxylase, on histamine levels in mouse tissues. Biochem Pharmacol 31: 2367-2370.

Masaki T, Chiba S, Yasuda T, Noguchi H, Kakuma T, Watanabe T et al (2004). Involvement of hypothalamic histamine $\mathrm{H} 1$ receptor in the regulation of feeding rhythm and obesity. Diabetes 53: 2250-2260. 
Masaki T, Yoshimatsu H (2006). The hypothalamic H1 receptor: a novel therapeutic target for disrupting diurnal feeding rhythm and obesity. Trends Pharmacol Sci 27: 279-284.

McCormick DA (1992). Neurotransmitter actions in the thalamus and cerebral cortex and their role in neuromodulation of thalamocortical activity. Prog Neurobiol 39: 337-388.

McCormick DA, Williamson A (1991). Modulation of neuronal firing mode in cat and guinea pig LGNd by histamine: possible cellular mechanisms of histaminergic control of arousal. J Neurosci 11: 3188-3199.

Monti JM (1993). Involvement of histamine in the control of the waking state. Life Sci 53: 1331-1338.

Monti JM, D'Angelo L, Jantos H, Pazos S (1988). Effects of a-fluoromethylhistidine on sleep and wakefulness in the rat. Short note. J Neural Transm 72: 141-145.

Moruzzi G (1972). The sleep-waking cycle. Ergeb Physiol 64: 1-165.

Nuutinen S, Lintunen M, Vanhanen J, Ojala T, Rozov S, Panula P (2011). Evidence for the role of histamine H3 receptor in alcohol consumption and alcohol reward in mice. Neuropsychopharmacol 36: 2030-2040.

Panula P, Yang HY, Costa E (1984). Histamine-containing neurons in the rat hypothalamus. Proc Natl Acad Sci USA 81: 2572-2576.

Parmentier R, Anaclet C, Guhennec C, Brousseau E, Bricout D, Giboulot $\mathrm{T}$ et al (2007). The brain H3-receptor as a novel therapeutic target for vigilance and sleep-wake disorders. Biochem Pharmacol 73: 1157-1171.

Parmentier R, Ohtsu H, Djebbara-Hannas Z, Valatx JL, Watanabe T, Lin JS (2002). Anatomical, physiological, and pharmacological characteristics of histidine decarboxylase knock-out mice: evidence for the role of brain histamine in behavioral and sleep-wake control. J Neurosci 22: 7695-7711.

Passani MB, Lin JS, Hancock A, Crochet S, Blandina P (2004). The histamine $\mathrm{H} 3$ receptor as a novel therapeutic target for cognitive and sleep disorders. Trends Pharmacol Sci 25: 618-625.

Revel FG, Gottowik J, Gatti S, Wettstein JG, Moreau JL (2009). Rodent models of insomnia: a review of experimental procedures that induce sleep disturbances. Neurosci Biobehav Rev 33: 874-899.

Rizk A, Curley J, Robertson J, Raber J (2004). Anxiety and cognition in histamine H3 receptor - I - mice. Eur J Neurosci 19: 1992-1996.

Sakai K, El Mansari M, Lin JS, Zhang JG, Vanni-Mercier G (1990). The posterior hypothalamus in the regulation of wakefulness and paradoxical sleep. In: Mancia M, Marini G (eds.) The diencephalon and sleep. Raven: New York, pp 171-198.
Schwartz JC, Arrang JM, Garbarg M, Pollard H, Ruat M (1991). Histaminergic transmission in the mammalian brain. Physiol Rev 71: 1-51.

Spiegel K, Leproult R, Van Cauter E (1999). Impact of sleep debt on metabolic and endocrine function. Lancet 354: 1435-1439.

Spiegel K, Tasalie E, Penev P, Van Cauter E (2004). Sleep curtailment in healthy young men is associated with decreased leptin levels, elevated ghrelin levels, and increased hunger and appetite. Ann Intern Med 141: 846-850.

Takahashi K, Lin JS, Sakai K (2006). Neuronal activity of histaminergic tuberomammillary neurons during wake-sleep states in the mouse. J Neurosci 26: 10292-10298.

Takahashi K, Suwa H, Ishikawa T, Kotani H (2002). Targeted disruption of $\mathrm{H} 3$ receptors results in changes in brain histamine tone leading to an obese phenotype. J Clin Invest 110: 1791-1799.

Tokita S, Takahashi K, Kotani H (2006). Recent advances in molecular pharmacology of the histamine systems: physiology and pharmacology of histamine $\mathrm{H} 3$ receptor: roles in feeding regulation and therapeutic potential for metabolic disorders. J Pharmacol Sci 101: 12-18.

Toyota H, Dugovic C, Koehl M, Laposky AD, Weber C, Ngo K et al (2002). Behavioral characterization of mice lacking histamine H(3) receptors. Mol Pharmacol 62: 389-397.

Turrigiano GG (2008). The self-tuning neuron: synaptic scaling of excitatory synapses. Cell 135: 422-435.

Valatx JL (1971). Long-term recording of cerebral, muscular and ocular electric activities in mice. $C R$ Seances Soc Biol Fil 165: $112-115$.

Valatx JL, Bugat R (1974). [Genetic factors as determinants of the waking-sleep cycle in the mouse (author's transl)]. Brain Res 69: 315-330.

Vanni-Mercier G, Gigout S, Debilly G, Lin JS (2003). Waking selective neurons in the posterior hypothalamus and their response to histamine $\mathrm{H} 3$-receptor ligands: an electrophysiological study in freely moving cats. Behav Brain Res 144: 227-241.

Watanabe T, Taguchi Y, Shiosaka S, Tanaka J, Kubota H, Terano Y et al (1984). Distribution of the histaminergic neuron system in the central nervous system of rats; a fluorescent immunohistochemical analysis with histidine decarboxylase as a marker. Brain Res 295: 13-25.

Yanai K, Watanabe T, Hatazawa J, Itoh M, Nunoki K, Hatano K et al (1990). Visualization of histamine $\mathrm{H} 1$ receptors in dog brain by positron emission tomography. Neurosci Lett 118: 41-44. 